\title{
Solid-State Fermentation as a Novel Paradigm for Organic Waste Valorization: A Review
}

\author{
Noraziah Abu Yazid ${ }^{1}$, Raquel Barrena ${ }^{1}$, Dimitrios Komilis ${ }^{1,2}$ and Antoni Sánchez ${ }^{1, *}$ \\ 1 Composting Research Group, Department of Chemical, Biological and Environmental Engineering, \\ Universitat Autònoma de Barcelona, 08193 Bellaterra, Barcelona, Spain; noraziah.abuyazid@uab.cat (N.A.Y.); \\ raquel.barrena@uab.cat (R.B.); dkomilis@env.duth.gr (D.K.) \\ 2 Department of Environmental Engineering, Democritus University of Thrace, University Campus, \\ 69100 Komotini, Greece \\ * Correspondence: antoni.sanchez@uab.cat; Tel.: +34-935-811-019; Fax: +34-935-812-013
}

Academic Editor: Vincenzo Torretta

Received: 29 November 2016; Accepted: 31 January 2017; Published: 8 February 2017

\begin{abstract}
The abundance of organic solid waste throughout the world has become a common issue that needs complete management at every level. Also, the scarcity of fuel and the competition between food and substance as an alternative to a petroleum-based product has become a major problem that needs to be properly handled. An urge to find renewable substances for sustainable development results in a strategy to valorize organic solid waste using solid state fermentation (SSF) and to manage the issue of solid wastes in a green approach. This paper reviews management of solid wastes using SSF, with regard to its current application, advantages and challenges, downstream processing in SSF, economic viewpoint, and future perspectives.
\end{abstract}

Keywords: solid state fermentation (SSF); downstream processing; organic wastes; value-added; enzymes; organic acids; biopesticides; biosurfactants; aroma compounds

\section{Introduction}

The generation of organic solid waste is dramatically increasing each year. The problems related to organic solid waste disposal have become more pronounced in recent years due to the rapid pace of development towards modernization throughout the world. Most of the organic waste is composed of household food waste, agricultural waste, human and animal wastes, etc. which are normally used as animal feed, incinerated or go to landfill sites [1]. However, incineration is an expensive disposal method and causes air pollution, while in landfills the organic waste is broken down by microorganisms and forms leachate that can contaminate the groundwater [2]. In addition, the degradation of organics in these conditions produces methane, which is 25 times more harmful greenhouse gas compared to carbon dioxide [3]. Incorrect waste management practices can result in public health and environmental problems, regarding issues such as odors and diseases [4]. Nevertheless, organic wastes are comprised of materials rich in sugars, minerals, and proteins that could be used for other processes as substrates or raw materials. Since the cultivation of microorganism requires carbon, nutrient, and moisture, organic waste could be a good candidate to provide the appropriate conditions for the development of microorganisms.

In this view, solid state fermentation (SSF) is presented as a promising technology for waste valorization through the bioconversion of organic wastes used as either substrate or inert support [5], whilst microorganisms will play a role in the degradation of organic wastes into its constituents to convert them into high value-added products. SSF shows sustainable characteristics in the bioconversion of solid wastes that have been proved to be able to give high efficiency in terms of product yields and productivities, low energy consumption, and solving disposal problems $[1,6]$. 
SSF is a process carried out with microorganisms growing on solid and moist substrates that act as nutrient sources and support the microbial growth in the absence or near absence of water $[7,8]$. SSF is not a new technology in bioprocessing since it has been mainly applied in the Asian region from ancient time, but recently it is gaining a lot of attention due to the increasing use of different types of organic wastes and the larger production of added-value products [5,9]. The search for sustainable and green processes to transform traditional chemical processes also highlights the potential of SSF. Thus, the bioconversion of organic wastes into valuable bio-products could substitute non-renewable materials and transform chemical processes into cleaner practices in the industrial sector. The particular interest of SSF is due to its relatively simple as a process that uses abundant low-cost biomaterials with minimal or no pre-treatment for bioconversion, less waste water generation, and the capacity for simulating similar microenvironments favorable to microorganism growth [10]. Similarly, SSF simulates natural microbiological processes such as composting and ensiling [11].

The present paper attempts to present routes for organic waste valorization using SSF technology with regard to recent applications and developments in SSF.

\section{Organic Waste and Its Potential}

Organic waste can be practically defined as any material or unused by-product from a process that is biodegradable and comes from either plant or animal. The main forms of organic waste are household food waste, agricultural waste, industrial waste, and human and animal waste. Organic waste tends to be degraded over time by other organisms depending on its composition and moisture content. The composition of organic waste varies from the nature of the original material. Depending on the type of organic waste, SSF can be applied with the aim of producing different valuable bio-products [9,12-14]. In this sense, Table 1 summarizes the use of different organic wastes with their potential to produce bio-products.

Table 1. List of organic wastes and their potential use in solid state fermentation (SSF) to obtain value-added bio-products.

\begin{tabular}{|c|c|c|c|c|}
\hline $\begin{array}{c}\text { Category of } \\
\text { Organic Waste }\end{array}$ & $\begin{array}{c}\text { Type of } \\
\text { Products/Processes }\end{array}$ & Waste Materials/Residues & Potential Use & References \\
\hline \multirow[t]{2}{*}{$\begin{array}{l}\text { Municipal/domestic } \\
\text { food waste }\end{array}$} & Kitchen waste & $\begin{array}{l}\text { Preparation waste, leftover } \\
\text { food, sludge, cocoyam peels }\end{array}$ & $\begin{array}{l}\text { Biopesticides, animal feedstuff, } \\
\text { organic acids, antibiotics }\end{array}$ & {$[15,16]$} \\
\hline & $\begin{array}{l}\text { Commercial/ } \\
\text { marke/hotel }\end{array}$ & $\begin{array}{l}\text { Used coffee grounds, used } \\
\text { tea bags, waste bread, } \\
\text { leftover, expired } \\
\text { foods, sludge }\end{array}$ & $\begin{array}{c}\text { Enzymes, animal feedstuff, } \\
\text { biopesticides, } \\
\text { bioethanol, bioplastics }\end{array}$ & {$[17,18]$} \\
\hline \multirow[t]{7}{*}{$\begin{array}{l}\text { Industrial organic } \\
\text { waste }\end{array}$} & $\begin{array}{l}\text { Animal products/ } \\
\text { tannery/ } \\
\text { slaughterhouse }\end{array}$ & $\begin{array}{l}\text { Skin, hides, fleshing wastes, } \\
\text { fats, horns, shaving wastes, } \\
\text { bones, liver, intestines }\end{array}$ & $\begin{array}{l}\text { Enzymes, animal feedstuff, } \\
\text { glues, surfactants, } \\
\text { lubricants, fillers }\end{array}$ & [19-22] \\
\hline & $\begin{array}{l}\text { Paper/wood } \\
\text { industry }\end{array}$ & Pulp, sawdust & Enzymes, bioethanol, biofuels & [23] \\
\hline & Sugar industry & Molasses & $\begin{array}{c}\text { Enzymes, } \\
\text { fructo-oligosaccharides }\end{array}$ & [24] \\
\hline & Poultry processing & $\begin{array}{l}\text { Skin, blood, fats, hairs, } \\
\text { feathers, bones, liver, } \\
\text { intestines, wings, } \\
\text { trimmed organs }\end{array}$ & $\begin{array}{c}\text { Enzymes, animal } \\
\text { feedstuff, biofertilizers }\end{array}$ & [25] \\
\hline & $\begin{array}{l}\text { Marine products } \\
\text { processing }\end{array}$ & $\begin{array}{l}\text { Shells, roes, pincers, } \\
\text { trimmed parts }\end{array}$ & $\begin{array}{l}\text { Enzymes, bioactive } \\
\text { compounds }\end{array}$ & {$[26,27]$} \\
\hline & $\begin{array}{c}\text { Cereals and } \\
\text { spices processing }\end{array}$ & $\begin{array}{l}\text { Husk, hull, chaff, } \\
\text { stalks, residues }\end{array}$ & Enzymes, activated carbon & [28] \\
\hline & $\begin{array}{l}\text { Fruits and } \\
\text { vegetables } \\
\text { processing }\end{array}$ & $\begin{array}{l}\text { Skin, peels, pomace, fiber, } \\
\text { kernel, stones, seeds }\end{array}$ & $\begin{array}{l}\text { Pectinolytic enzymes, biofuels, } \\
\text { animal feed, organic acids }\end{array}$ & {$[29,30]$} \\
\hline
\end{tabular}


Table 1. Cont.

\begin{tabular}{|c|c|c|c|c|}
\hline $\begin{array}{l}\text { Category of } \\
\text { Organic Waste }\end{array}$ & $\begin{array}{c}\text { Type of } \\
\text { Products/Processes }\end{array}$ & Waste Materials/Residues & Potential Use & References \\
\hline & Nuts processing & Shells, coir, pith & $\begin{array}{l}\text { Biopulping, biochar, } \\
\text { activated carbon }\end{array}$ & {$[31]$} \\
\hline \multirow[t]{3}{*}{$\begin{array}{l}\text { Agricultural } \\
\text { organic waste }\end{array}$} & $\begin{array}{l}\text { Corn, wheat, rice, } \\
\text { soya, coffee, } \\
\text { sugarcane, barley }\end{array}$ & $\begin{array}{l}\text { Fiber, meal, straw, bran, } \\
\text { husk, pulp, bagasse }\end{array}$ & $\begin{array}{l}\text { Enzymes, animal feedstuff, } \\
\text { biofuels, bioethanol, furfural, } \\
\text { chemical feedstock, } \\
\text { biopolymers, organic acids }\end{array}$ & {$[1,32]$} \\
\hline & Cattle, broiler & Fleshing wastes, dung, litter & $\begin{array}{l}\text { Animal glue, animal feed } \\
\text { supplement, methane } \\
\text { production, biochar, } \\
\text { activated carbon, } \\
\text { biofertilizers, biopesticide }\end{array}$ & {$[33-35]$} \\
\hline & Coconuts & Fibers, shell, kernel & $\begin{array}{l}\text { Resins, pigments, fillers, mats, } \\
\text { activated carbon, } \\
\text { tanning materials }\end{array}$ & {$[38-40]$} \\
\hline
\end{tabular}

\subsection{Agricultural Organic Waste}

Agricultural and agro-industrial activities generate a large amount of lignocellulosic by-products such as bagasse, straw, stem, stalk, cobs, fruit peel and husk, among others. These wastes are mainly composed of cellulose $(35 \%-50 \%)$, hemicellulose $(25 \%-30 \%)$, and lignin $(25 \%-30 \%)$ [41]. Typically, in lignocellulosic materials, the cellulose main constituent is glucose; hemicellulose is a heterogeneous polymer that is mainly comprised of five different sugars (L-arabinose, D-galactose, D-glucose, D-mannose, and D-xylose) and some organic acids; whereas lignin is formed by a complex three-dimensional structure of phenylpropane units [1].

Despite the complex structure and composition of agricultural organic wastes, SSF has been successfully applied to the production of hydrolytic and ligninolytic enzymes [31,42,43]. Lignin peroxidase has been produced using corn cobs as a substrate in SSF [44]. Furthermore, considering the rising price and shortage of grains as a custom animal feed, lignocellulosic materials have a great potential to produce edible animal feedstuff [45]. However, the direct application for animal feedstuff is limited because of the presence of lignin that reduces its digestibility. Several pre-treatments of straw have been made using SSF for cellulose and lignin degradation to increase the digestibility of the feed [46]. In this sense, SSF can have a great potential in producing enzymes to improve the digestibility of rich fiber materials such as soybean cotyledon [47]. Jatropha seed cake has been reported for the production of cellulases through SSF without any pre-treatment [13]. Several authors present other uses for similar materials such as the reinforcement of composite materials for application in building materials, furniture, fishnet, etc. [39,40] or as activated carbons [38]. Agricultural organic wastes also include livestock manure. Cow dung was reported to have a high nitrogen content that made it suitable for methane production [33,34]. The production of biochar and activated carbon were favored by utilization of chicken manure and cow dung [48,49]. Furthermore, high-quality biofertilizer was produced employing liquid amino acid hydrolyzed from animal carcasses as an additive to mature compost of chicken or pig manure by SSF [50].

\subsection{Industrial Organic Waste}

Industrial organic wastes include any organic by-product from a large variety of industries such as slaughterhouses, fruit and vegetable processing plants, poultry processing, paper and pulp manufacturing, the sugar industry, and the dairy industry, among others. Most of these wastes have the potential to be used as a substrate or support in SSF processes to produce high value products. 
For instance, sawdust, which is an easily available by-product of the wood industry, has been used as a support substrate in SSF to obtain high laccase production by white rot fungi Coriolopsis gallica [51]. The leather industry and slaughterhouses generate many organic wastes containing protein such as animal fleshing, hair wastes, skin trimming, keratin wastes, chrome shaving, and buffing wastes that are being underutilized. Several authors have reported the utilization of animal fleshing as a substrate in SSF for protease production [52]. The mixture of hair wastes with activated sludge or anaerobically digested sludge showed a high yield of protease production $[19,20]$. By-products of the sugar industry such as molasses and sugarcane bagasse have been reported in the production of invertase by SSF [53]. Molasses also was chosen as a low-cost substrate to replace an expensive feedstock (cane sugar) in ethanol production [54]. Additionally, tapioca industry waste which contains considerable organic matter with a strong odor that could cause environmental pollution has been successfully converted into poly-3-hydroxybutyrate (PHB) via SSF, thus possibly becoming an alternative process and reducing the total production cost [55]. Food processing industries generate many by-products able to be used in SSF for producing valuable bio-products $[28,56]$. The use of fruits and vegetable waste for production of organic acid and vital enzymes has been widely reported [30]. Due to its high and easily degradable organic content, vegetable wastes show a great potential for energy bioconversion, particularly in biofuel production [57]. Crustacean by-products, generated in industrial seafood processing, have been reported in the production of chitinase and chitosanase with a wide range of applications in biomedical, food and agrochemical sectors $[58,59]$. Fish processing wastes in SSF are favorable since the waste is easy to obtain at low-cost and provides appropriate conditions for microorganism cultivation. Fish processing wastes, rich in lipids and proteins, have been found suitable to produce esterase, a product with a versatile industrial application in organic chemical processing, in detergent formulations, and in the surfactant and oleochemical industry [60].

\subsection{Municipal/Domestic Food Waste}

Most countries around the world are facing a great challenge to manage domestic food waste as it is wet, putrescible, and sometimes mixed with inorganic waste (impurities). Generally, the composition of domestic food waste is complex and includes oil, water, as well as spoiled and leftover foods from kitchen wastes and markets. These substances are chemically comprised of starch, cellulose, protein, fats, lipids, and other organic matter. High moisture and salt contents lead to rapid decomposition of the organic wastes and produce unpleasant odors that can attract flies and bugs, which are vectors for various diseases. Apart from being perishable, municipal solid waste including household kitchen waste and domestic food waste from restaurants and markets contains high lignocellulosic materials that could be exploited to produce valuable bio-products. Domestic food wastes such as waste bread, savory, waste cakes, cafeteria waste, fruits, vegetables and potato peel wastes have been reported as a suitable substrate for glucoamylase enzymes production by Aspergillus awamori via SSF technology [61,62]. Bread waste has been used to produce amylase [63], whereas municipal solid waste and kitchen waste residues principally composed of potato peel, orange peel, onion peel, carrot peel, cauliflower leaves, banana stalks and pea pods have been used to produce cellulase by SSF $[64,65]$. The cultivation of selected industrial yeast strains using orange peel as a substrate resulted in a high yield of aroma esters [66]. The utilization of household food wastes with high dry content to produce high yields of ethanol by SSF has also been reported in several studies $[67,68]$. Likewise, mixed food wastes collected from restaurants and inoculated with fungal inoculum can produce glucoamylase-rich media and protease-rich media by SSF, suitable to be used as a feedstock to produce succinic acid which has a wide range of applications including laundry detergents, plastics, and medicine production [69]. Cocoyam peel is a common household kitchen waste in Nigeria presenting a capability to become a very useful substrate for oxytetracyclines, which are an important antibiotic to treat many infections [70]. The complex composition of food wastes also makes them suitable for microbial growth, having potential to produce Bacillus thuringiensis (Bt) biopesticide through SSF [16]. 


\section{General Aspects of Solid State Fermentation}

Solid state fermentation (SSF) has received great attention in the past years. The successful development of bioprocesses in SSF is linked to several general aspects including the suitability of different types of microorganisms, substrates, and process parameters. There are various types of microorganisms used in the SSF process including fungi, yeasts, and bacteria. However, fungi and yeast are the most commonly reported for the reason that SSF can provide a similar natural habitat, which has low water activity in the fermentation media. The most common yeast genera reported in SSF are Candida, Saccharomyces and Aureobasidium [71], while common fungal genera are Aspergillus, Penicillium, and Rhizopus, which have a broad range of species for the production of a wide number of valuable bio-products through SSF [12]. Despite SSF seeming to be more favorable for fungi and yeast growth, there is also increasing evidence of bacteria successfully used in producing bio-products in SSF. The most common bacteria genera used are Bacillus and Streptomyces [11,72]. There are a lot of studies reporting the use of filamentous fungi, mainly chosen in SSF because of their ability to produce thermostable enzymes of high commercial value [72-75]. However, there are also several studies reporting that thermostable enzymes can be produced by bacteria strains especially from Bacillus species [76-79].

Selection of suitable substrates also plays a key role in an efficient and economical production of the desired product. In selecting proper substrates for the SSF process, it is important to ensure the availability and cost of the substrates. They can supply appropriate nutrients and physical support for the development of microorganisms in SSF. Organic wastes from agricultural, industrial processing, and domestic food waste are the most suitable substrates to be used due to their abundance at low or no cost and their chemical composition. Additionally, by using these organic wastes as substrates their environmental pollution problems can be minimized. However, in some cases, an additional supplement has to be added to the organic wastes. In other cases, a chemical or mechanical pretreatment (especially for lignocellulosic materials) is necessary due to the inaccessibility of certain nutrients for microorganisms. For example, a chemical pre-treatment of municipal solid waste was performed to prepare the solid fraction for an easier microbial uptake in the production of cellulase [65]. Pulp and paper solid waste were pre-treated with acid hydrolysis in a microwave prior to SSF as a substrate to produce fumaric acid [80]. In the production of an anti-cancer pro-drug, camptothecine (CPT), by SSF, complex protein sources (whey concentrate powder) were added to soybean waste to enhance the productivity of Fusarium oxysporum producing a secondary metabolite [81].

Other important aspects to enhance the efficiency of SSF are the selection and optimization of process variables including initial moisture, particle size, $\mathrm{pH}$, temperature, media composition, sterilization, water activity, inoculum density, agitation, aeration, extraction of product and its downstream process [7]. Among these aspects, particle size and moisture content have been mainly studied, reported and reviewed by others $[9,11,72,82]$. Ideally, it is apparent that small substrate particles could provide a large surface area for microbial attachment. Yet, extremely small particles would result in substrate agglomeration that could affect oxygen transfer, thus retarding microorganism development. However, although a large particle size of the substrate provides better aeration efficiency, it can limit the surface area for microbial attachment $[6,7,82]$. Hence, the conditions that are favorable in a particular process are an aspect that needs to be thoroughly assessed. Moisture content also has a significant role in SSF as bacteria and fungi have different moisture content requirements. Fungi need lower moisture content around $40 \%-60 \%$ [11] whereas bacteria can require high moisture content $(60 \%-85 \%)$ [72]. The optimum moisture content in a solid substrate is closely related to the correct nutrient and oxygen/carbon dioxide diffusion during fermentation [83]. High moisture content would decrease porosity, with the loss of the structure of the particles and interfere in oxygen diffusion. On the contrary, low moisture content can limit nutrient solubility hindering microorganism development. An increase of temperature during the fermentation will indicate the growth of the microorganism. In aerobic fermentation, oxygen is supplied and exchanged with carbon dioxide and heat is generated by microorganisms, leading to a temperature increase. In some cases, high 
temperatures will negatively affect the growth of microorganisms and product formation [7]. However, in other cases, high temperatures increase the yield of the enzyme produced $[19,20,84]$.

These general aspects are relevant to point out a general idea to design an efficient strategy using organic wastes in SSF according to the product required and considering the cost and waste availability. Figure 1 summarizes the whole general processes involved in the valorization of organic waste via SSF.

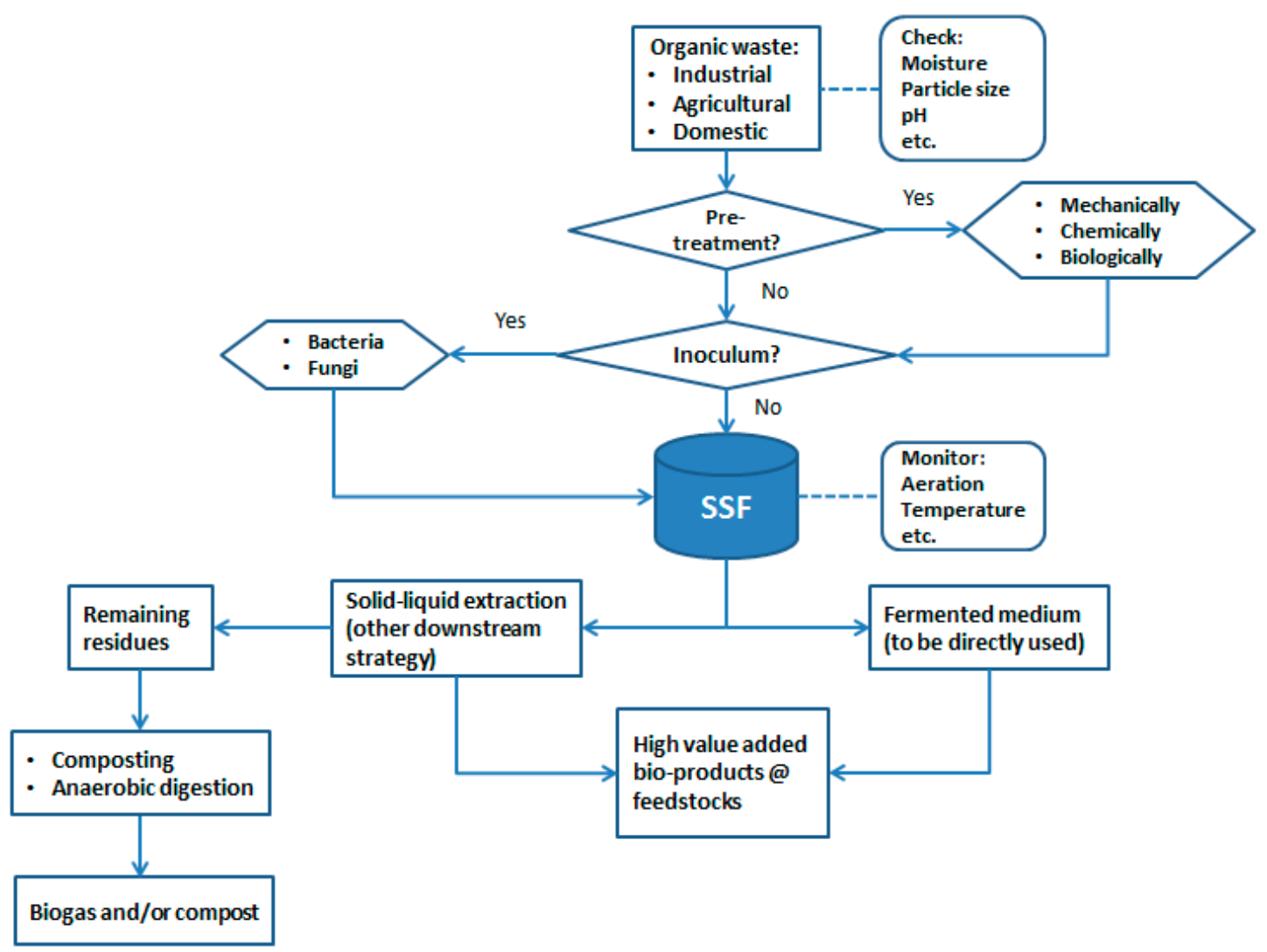

Figure 1. Flowchart of valorization of organic waste to produce valuable bio-products using solid state fermentation (SSF).

\section{Advantages and Challenges of Solid State Fermentation}

In recent years, there has been an increasing trend for using SSF in the biotechnology field due to its simplicity and ability to perform the bioconversion of low-cost solid substrates, in some cases achieving higher productivity than that of submerged fermentation $(\mathrm{SmF})[85,86]$, due to broth rheology problems that affect the transport phenomena and mass transfer in a SmF reactor [87]. In addition, the lack of a liquid phase in SSF reduces waste water and lower down the risk of bacterial contamination. In this sense, SSF offers an advantage by using unsterilized substrates and creates non-strict sterile conditions for the process [88]. Also, SSF provides a simple media preparation with the reduction of reagents use, since the media normally contain the appropriate nutrient for the process and present negligible foaming problems during the process. As a matter of fact, the process requires low consumption of energy since agitation and sterilization are not always necessary. Similarly, this process reduces purification costs due to higher end product concentration or by using the product in a crude form [71].

In spite of these advantages, SSF also faces several challenges such as mass and heat transfer, scale-up, biomass estimation, and recovery and operational control. In addition, the utilization of natural substrates is often limited by their poor reproducibility and heterogeneity [89]. Also, the heterogeneity of the substrate related to porosity can lead to mass and heat transfer problems 
in SSF [90]. Moreover, the diffusion of mass and heat in SSF depends on aeration which may differ according to the substrate types. In the small scale, an appropriate aeration allows heat dissipation and a regulation of the mass moisture level. However, the removal of heat generated during metabolic growth can be a problem at the large scale. The high solid concentration requires a large quantity of air [91]. Furthermore, biomass determination is quite a challenge in SSF, especially involving fungi that usually develop a tight interaction between mycelia and solid substrate making difficult the complete recovery of biomass [92]. Due to this difficulty in biomass quantification, a lack of important basic scientific engineering and fermentation operational control is often found in publications and only a qualitative or empirical characterization is done [93]. The same happens when establishing kinetics of reactions in SSF.

\section{Applications of Solid State Fermentation}

SSF has opened a new paradigm of bioconversion of organic solid wastes through the production of biologically active metabolites both at the lab and industrial scale. The application of SSF in the production of different bio-products has been widely reported including enzymes, organic acids, biofertilizers, biopesticides, biosurfactants, bioethanol, aroma compounds, animal feed, pigments, vitamins, antibiotics, etc.

\subsection{Enzymes Production}

In search of green technology, enzyme production has received a lot of attention in industrial biotechnology processes with the objective of replacement of chemical processes having potentially negative effects on humans and the environment. Various enzymes emerging from biotechnology processes, mainly from submerged fermentation, are playing a key role in a large number of industrial processes. In recent years, the production of enzymes from SSF has gained attention due to the simplicity, high productivity, and stability that make them suitable for industrial processes. Several reviews on the production of enzymes from SSF have been published in recent years [5,9,11,12]. Fungi, yeasts, and bacteria are capable of producing various enzymes through SSF, as the environment in SSF is favorable for most microorganisms. In Table 2, a compilation of several organic solid wastes used as substrates for enzyme production with or without inoculation of specific strains is shown.

Table 2. List of several enzymes produced and organic waste used as substrates in SSF.

\begin{tabular}{cccc}
\hline Enzyme & Microorganism & Substrate & Reference \\
\hline cellulase & T. reesei & Municipal solid waste & {$[65]$} \\
& Thermoascus aurantiacus & Jatropha deoiled seed cake & {$[13]$} \\
A. niger & kitchen waste & {$[64]$} \\
& Penicillium sp. & empty fruit bunches & {$[43]$} \\
T. reesei & wheat bran & {$[94]$} \\
A. niger & groundnut husks & {$[95]$} \\
Trichoderma viridae & banana peel & {$[96]$} \\
Candida tropicalis, & Ginkgo biloba residues & {$[97]$} \\
A. oryzae & wheat bran & {$[98]$} \\
A. niger & wheat bran & {$[99]$} \\
Trametes hirsuta & soybean bran & {$[100]$} \\
T. reesei & A. fumigatus & lignocellulosic materials & {$[73]$} \\
T. harzianum & wheat bran & {$[101]$} \\
T. asperellum & A. niger & lignocellulosic materials & {$[102]$} \\
& rice straw and wheat bran & {$[103]$} \\
& grass powder & {$[104]$} \\
& A.nidulans & black gram residues & {$[105]$} \\
Aspergillus sp. & banana peel, pineapple peel & {$[106]$} \\
A. awamori & domestic food waste & {$[61]$} \\
A. awamori & bread waste & {$[62,107]$} \\
Bacillus sp. & mustard oil seed cake & {$[108]$} \\
Thermomyces sp. & soy and bread waste & {$[63]$} \\
\hline
\end{tabular}


Table 2. Cont.

\begin{tabular}{|c|c|c|c|}
\hline Enzyme & Microorganism & Substrate & Reference \\
\hline \multirow{14}{*}{ protease } & Bacillus subtilis & wheat bran and wheat rava & [109] \\
\hline & A. fumigatus & wheat bran & [110] \\
\hline & A. niger & $\begin{array}{l}\text { wheat bran, soybean meal, cottonseed } \\
\text { meal, orange peel }\end{array}$ & [111] \\
\hline & Pseudomonas aeruginosa & Jatropha curcas seed cake & [112] \\
\hline & A. awamori & bread waste & {$[62,107]$} \\
\hline & A. oryzae & wheat bran, soya bran & [113] \\
\hline & Bacillus sp. & green gram husk & [114] \\
\hline & A. fumigatus & wheat bran & [115] \\
\hline & B. cereus & cow dung & [116] \\
\hline & $\begin{array}{c}\text { Candida tropicalis, } \\
\text { A. oryzae }\end{array}$ & Ginkgo biloba residues & [97] \\
\hline & Thermus sp. & soy fiber & [117] \\
\hline & N.S. & hair waste, activated wastewater sludge & [19] \\
\hline & Thermoactinomyces sp. & agricultural and household waste & [118] \\
\hline & N.S. & $\begin{array}{l}\text { hair waste, anaerobic digested } \\
\text { wastewater sludge }\end{array}$ & [20] \\
\hline keratinase & Paenibacillus woosongensis & dry feathers & [119] \\
\hline \multirow[t]{3}{*}{ lipase } & Pseudomonas aeruginosa & Jatropha curcas seed cake & [112] \\
\hline & N.S. & vegetable oil refining waste & [120] \\
\hline & A. niger & oil palm waste residues & [121] \\
\hline \multirow[t]{6}{*}{ xylanase } & A. japonicus & castor bean waste & [122] \\
\hline & A. tubingensis & wheat straw & [123] \\
\hline & B. pumilus & wheat bran & {$[124]$} \\
\hline & T. harzianum & wheat bran & {$[101]$} \\
\hline & Colletotrichum graminicola & wheat bran & [125] \\
\hline & A. nidulans & black gram residues & [105] \\
\hline \multirow[t]{2}{*}{ inulinase } & A. ficuum & wheat bran & [126] \\
\hline & Kluyveromyces marxianus & sugarcane bagasse & [127] \\
\hline \multirow[t]{2}{*}{ laccase } & Coriolopsis gallica & sawdust waste & [51] \\
\hline & Trametes versicolor & oak sawdust & [128] \\
\hline esterase & B. altitudinis & fish processing waste & {$[60]$} \\
\hline lignin peroxidase & Ganoderma leucidum & waste corn cob & [44] \\
\hline invertase & A. niger & molasses and sugarcane bagasse & [53] \\
\hline \multirow[t]{2}{*}{$\beta$-xylosidase } & A. tamarii & ground oats & [129] \\
\hline & Colletotrichum graminicola & wheat bran & [125] \\
\hline$\beta$-glucosidase & Colletotrichum graminicola & wheat bran & [125] \\
\hline $\begin{array}{c}\text { multienzyme } \\
\text { protease, } \\
\text { xylanase, } \\
\text { cellulase, } \\
\text { endomylase }\end{array}$ & A. awamori & babassu cake & [130] \\
\hline
\end{tabular}

N.S.: non-specified.

In SSF, non-sterilized and non-inoculated media are often suitable. This aspect can positively affect the economic feasibility for the production of enzymes at the industrial scale. For example, protease production from hair waste and waste water sludge in a $4.5 \mathrm{~L}$ reactor $\left(469 \mathrm{U} \cdot \mathrm{g}^{-1} \mathrm{DM}\right)$ has been successfully scaled up to a $10 \mathrm{~L}$ reactor resulting in a stable proteolytic activity of $435 \mathrm{U} \cdot \mathrm{g}^{-1} \mathrm{DM}$ [20]. Also, the production of lipase from the mixture of winterization residue and waste water sludge in a $4.5 \mathrm{~L} \mathrm{SSF}$ reactor under non-sterilized conditions resulted in a high lipolytic activity $\left(120,000 \mathrm{U} \cdot \mathrm{g}^{-1} \mathrm{DM}\right)$ [120]. It has been proved that non-sterilized conditions are applicable in the production of enzymes by SSF even without specific inoculation [117].

Kriaa and Kammoun [131] compared the production of glucose oxidase by Aspergillus tubingensis in SSF and SmF. Preliminarily, both conditions were compared using glucose and gluconic acid as substrates which led to higher activity of glucose oxidase in SSF $\left(170.59 \mathrm{U} \cdot \mathrm{mL}^{-1}\right)$ compared to $\mathrm{SmF}\left(43.73 \mathrm{U} \cdot \mathrm{mL}^{-1}\right)$. Then, the production of glucose oxidase was carried out using a mixture of agro-residues such as wheat bran, molasses and fish meal. An enhanced yield was observed, 74\% higher than preliminary SSF and SmF. Similarly, peptidase production by Aspergillus fumigatus in 
SSF using wheat bran and SmF using casein as a substrate was compared. An improved yield of peptidase production, approximately 30 times higher, was obtained through SSF compared to SmF [115]. In another comparative study among SSF, slurry state fermentation (SISF) and SmF, revealed that maximum $\beta$-xylosidase was obtained in SSF $\left(33.7 \mathrm{U} \cdot \mathrm{mL}^{-1}\right)$ followed by SISF $\left(24.9 \mathrm{U} \cdot \mathrm{mL}^{-1}\right)$ and $\mathrm{SmF}\left(5.5 \mathrm{U} \cdot \mathrm{mL}^{-1}\right)$ [129].

The enzymes produced by SSF maintain a similar or enhanced capability for chemical processes or commercial enzymes normally produced by SmF. Several studies have been successfully applied to the crude enzymes produced from SSF to industrial processes such as dehairing of hides, hydrolysis of lignocellulosic materials, detergent formulation, deinking and biobleaching paper waste, bioethanol production, xylitol production, silver recovery from X-ray films, etc.

Tanning and leather industries release a lot of hazardous chemicals. In this sense, some authors have explored the use of crude enzymes such as protease, keratinase, and amylase from SSF in leather processing as an alternative to chemical processes. Crude protease produced from hair waste and waste water sludge in SSF showed a high potential to substitute chemical dehairing [19,20]. The results in cowhide dehairing were as efficient as using chemical and commercial powder enzymes, indicating the economic viability of the process. Likewise, the crude protease produced by Bacillus cereus from agro-industrial residues and cow dung as substrates in SSF were effectively used for the dehairing of goat hides for $18 \mathrm{~h}$ at $30{ }^{\circ} \mathrm{C}$ [116]. In other studies, the use of crude keratinase in dehairing of goat skins has been also reported [119]. The keratinase produced by Paenibacillus woosongensis by SSF employing chicken feather and rice straw as substrates, showed similar or improved characteristics to using chemical treatments, without causing damage to the collagen layers after the dehairing process. Integrated bioprocessing in leather processing including detaining and fiber opening normally needs a commercial enzyme. This enzyme is expensive for the regular processes of tanning and contains some added stabilizers that could contribute to the pollution of the effluent. Correspondingly, amylase produced by Bacillus subtilis on wheat bran through SSF showed a good performance in the fiber opening process developed on goat skins in comparison to chemicals and commercial enzymes. Besides, the employment of crude amylase during the process showed a lower pollution load (COD, TS) [109].

Crude cellulase produced from agricultural residues under SSF has been used in the saccharification of lignocellulosic materials such as rice straw, sugarcane bagasse, corn cob, fruits peel, and wheat bran enhanced the sugar yield for bioethanol production [98-100,102,103]. The utilization of grass powder as a carbon source in the production of cellulase and hemicellulase by Phanerochaete chrysosporium by SSF yielded an efficient enzyme complex which could be employed for hydrolysis of rice husk. Then, the hydrolysate was used by Clostridium beijerinckii and resulted in higher biohydrogen production, which was superior to other values reported [104]. Production of cellulase and xylanase by SSF inoculating Trichoderma harzianum showed a better activity and stability at optimum $\mathrm{pH}$ and temperature. The crude enzyme complex produced by SSF enhanced the toner removal of photocopier waste papers with superior strength properties (fiber and microfibrils) compared to chemical treatment, and the enzyme complex improved the brightness and drainage as well [101]. Similarly, the crude enzyme complex (cellulase, xylanase, $\beta$-glucosidase) by Aspergillus nidulans cultivated on low-cost crop residues as a substrate under SSF was efficiently used in the saccharification of pearl millet stover and bio-deinking of mixed office waste paper with enhanced physical properties [105]. Verma et al. [118] reported the use of crude protease produced from low cost agricultural and household waste by Thermoactinomyces sp. via SSF. The enzyme was used as an additive to commercial detergents as an alternative to caustic soda. Interestingly, the crude enzyme also showed gelatinase activity capable of hydrolyzing the gelatine layer locking the silver salt on used X-ray film, for silver recovery.

\subsection{Organic Acids Production}

Organic acids are categorized as the third largest products among biologically produced compounds [132] and their application has been continuously increasing. Organic acids are known 
to hold extensive and versatile applications in many industries such as those for food and beverage preservation, animal feed production, soap manufacturing, medicines and pharmaceutical products, industrial solvents, perfumes preparation, oil and gas stimulation treatments, among others. Organic acids such as citric acid, lactic acid, succinic acid, fumaric acid, humic acid, oxalic acid, gluconic acid, and gallic acid have been produced commercially both by chemical synthesis and biological fermentation. Over the past years, several attempts have been made to develop and produce organic acids using SSF. Several authors have evaluated the potential use of organic solid waste such as sugarcane bagasse, cassava bagasse, coffee husk, kiwi fruit peel, wheat bran, rice bran, pineapple waste or apple pomace in organic acid production by SSF $[1,9,30]$.

Citric acid is a weak acid that plays an important role in several industries such as food, cosmetics, pharmaceutical, and chemical products, etc. presenting an increase in its global demand over the last years. Aspergillus niger is a well-known citric acid producer, capable of using a wide variety of raw materials and achieving high yields. This acid has been mainly produced using SmF by A. niger using starch or sucrose-based media. However, the use of non-food materials (agro-industrial residues, fruit wastes, and other solid by-products) by SSF would be a greener approach for citric acid production. Fruit wastes such as pineapple pulp waste [133], grape peel [134], mixed fruit waste [135], apple pomace [136], orange peel [137], or banana peel [138,139] have been extensively studied to produce citric acid by SSF. When comparing SSF and SmF with $A$. niger growing on orange peel, the production of citric acid increased about 3-fold in SSF $\left(193.2 \mathrm{~g} \cdot \mathrm{kg}^{-1}\right)$ compared to $\mathrm{SmF}\left(73.6 \mathrm{~g} \cdot \mathrm{kg}^{-1}\right)$ [140]. The addition of methanol, ethanol, isopropanol or methyl acetate, copper, and zinc has been related to the enhancement of the production of citric acid [141]. The amount of citric acid ( $640 \mathrm{~g} \cdot \mathrm{kg}^{-1}$ orange peels) by $A$. niger grown on orange peels supplemented with molasses and 3.5\% methanol in the medium after $72 \mathrm{~h}$ fermentation [137] and with pineapple pulp as substrate showed higher yield in a medium with methanol $\left(5.25 \mathrm{~g} \cdot \mathrm{kg}^{-1}\right)$ compared to medium without methanol $\left(3.25 \mathrm{~g} \cdot \mathrm{kg}^{-1}\right)$ [133]. Similarly, the addition of $3 \%\left(\mathrm{v} \cdot \mathrm{w}^{-1}\right)$ ethanol and $4 \%\left(\mathrm{v} \cdot \mathrm{w}^{-1}\right)$ methanol to apple pomace as substrate increased the citric acid concentration up to $90 \%$ compared to the control study [136]. Likewise, the high amount of citric acid $\left(82 \mathrm{~g} \cdot \mathrm{kg}^{-1}\right)$ obtained after $72 \mathrm{~h}$ was reported with banana peel as substrate supplemented with $1 \%\left(\mathrm{v} \cdot \mathrm{w}^{-1}\right)$ methanol and $10 \mathrm{ppm}$ of copper ions [139]. However, other studies found that the addition of methanol was detrimental for citric acid production [140]. Goud et al. [134] reported that a higher yield of citric acid was obtained with a particle size of $0.63 \mathrm{~mm}$ compared to $0.25 \mathrm{~mm}$ and $0.15 \mathrm{~mm}$ particle size of grape peel in the medium, indicated that the production of citric acid by SSF was also influenced by this parameter.

Apart from fruit wastes, citric acid can also be produced from agro-industrial wastes such as oil palm empty fruit bunches [142], sugarcane bagasse [143], cassava bagasse [144], and biodiesel by-products [145] through SSF. Yadegary et al. [143] optimized citric acid production using sugarcane bagasse as a substrate by SSF using the Taguchi statistical method. Alkaline and acid pretreatment showed an increase in the yield production of $97.81 \mathrm{~g} \cdot \mathrm{kg}^{-1}$ and $87.32 \mathrm{~g} \cdot \mathrm{kg}^{-1}$ respectively, compared with untreated sugarcane bagasse yield of $75.45 \mathrm{~g} \cdot \mathrm{kg}^{-1}$. The production and scale up of citric acid can be influenced by operation parameters such as $\mathrm{pH}$, inoculum development, substrate concentration, incubation temperature, and bioconversion time as reported in the study with oil palm empty fruit bunches as a substrate under SSF [142]. The bioconversion of biodiesel by-product (tung cake and glycerine) by A. niger under SSF for the production of citric acid has also been reported. The high yield of citric acid obtained $\left(350 \mathrm{~g} \cdot \mathrm{kg}^{-1}\right)$ provides a feasible way to manage the solid waste economically [145].

Lactic acid is another organic acid that has many applications in food, pharmaceutical, cosmetics, and chemical industries. The demand is increasing as it acts as a precursor to produce poly-lactic acid (PLA) for biodegradable plastic production. It is commonly produced from fungi (Rhizopus sp.) and bacterial strains (Lactobacillus sp.) in fermentation. A study of comparison between a wild and mutant strain of Rhizopus sp. for lactic acid production from cassava peel using SSF, indicated that the mutant strain subjected to mutation by UV radiation yielded the highest production $\left(57.6 \mathrm{mg} \cdot \mathrm{g}^{-1}\right)$ while the 
wild strain only yielded $32.4 \mathrm{mg} \cdot \mathrm{g}^{-1}$ [146]. In an effort to reduce the production costs, several low-cost materials were used as a carbon source or support for L-lactic acid production by Lactobacillus sp. in SSF such as cassava bagasse [147], sugarcane bagasse [148], rice straw [149], wheat bran [150], tea waste [151], pine needles [152], etc. During the production of lactic acid, the nitrogen source also plays an important role in improving the yield. Several authors reported the utilization of wheat bran as substrate impregnated with low-cost nitrogen sources such as red lentil flour and baker's yeast substituting peptone and yeast extracts during the SSF process. As a result, higher yields up to $96 \%$ of lactic acid efficiency ( $g$ lactic acid produced per g substrate utilized) have been reported $[150,153]$.

El-Naggar et al. [154] investigated five cellulosic wastes included rice husks, wheat bran, corn cobs, wheat straw, and rice straw by A. glaucus, A. oryzae, and Penicillium purpurogenum. Through SSF, the production of high concentrations of levulinic acid $\left(46.15 \mathrm{mg} \cdot \mathrm{g}^{-1}\right)$ on corn cobs and oxalic acid $\left(43.20 \mathrm{mg} \cdot \mathrm{g}^{-1}\right)$ on rice husks by P. purpurogenum were studied. The production of oxalic acid was enhanced by the optimization of inoculum size and the initial substrate concentration. A. niger $\left(10^{6}\right.$ spores $\cdot \mathrm{g}^{-1}$ dry weight) and $5 \%\left(\mathrm{w} \cdot \mathrm{v}^{-1}\right)$ corn cob as a substrate in $0.1 \mathrm{~N} \mathrm{NaOH}$ solution which contributed to a maximum yield $\left(123 \mathrm{~g} \cdot \mathrm{kg}^{-1} \mathrm{DM}\right)$ [155]. Another remarkable route of waste valorization via SSF is the production of fumaric acid from pulp and paper solid waste from the paper industry. Das et al. [80] compared the production of fumaric acid by Rhizopus oryzae through SmF and SSF. The highest fumaric acid production was obtained from SSF (41.45 $\left.\mathrm{g} \cdot \mathrm{kg}^{-1} \mathrm{DM}\right)$ after 21 days with $75 \mu \mathrm{m}<\mathrm{x}<300 \mu \mathrm{m}$ particle size, whereas $23.47 \mathrm{~g} \cdot \mathrm{L}^{-1}$ of fumaric acid were produced through $\mathrm{SmF}$ after 48 days. Furthermore, humic acid that has a diverse application in agriculture, industry, the environment, and biomedicine has been commercially produced from non-renewable materials. Utilization of empty fruit bunches from oil palm processing by $T$. reesei for humic acid production by SSF provides an alternative for humic acid production [14].

\subsection{Biopesticides Production}

It is widely known that the use of chemical insecticides can cause harmful effects on human health as well as give environmental problems. The shift towards biopesticides has become more attractive in recent years. SSF was found to be the most suitable platform for biopesticide production as the spores produced in SSF are more stable and resistant to stress than those produced in SmF [8,88]. Both fungi and bacteria are able to produce biopesticides.

De Vrije [156] reviewed the development of fungal biopesticides produced by Coniothyrium minitans through SSF and its viable application on oilseed rape and lettuce, which were the most susceptible crops to have problems with the parasite Sclerotinia sclerotiorum. Employing continuous slow mixing $(0.2 \mathrm{rpm})$ in a scraped-drum reactor during biopesticide production by $C$. minitans on oats can overcome heat accumulation in the large scale with high spore yields $5 \times 10^{12}$ spores per $\mathrm{kg}$ of dry oats [157]. Production of spores from Clonostachys rosea on white rice grain in polyethylene bags $(20.5 \mathrm{~cm} \times 25 \mathrm{~cm})$ using SSF showed no significant effect on mixing yield with $1.1 \times 10^{8}$ spores.g ${ }^{-1} \mathrm{DM}$ with 15 days of fermentation [158]. Contrarily, spore production of a biocontrol agent $C$. rosea on wheat bran and maize meal in a new developed SSF reactor showed an efficient yield of $3.36 \times 10^{10} \mathrm{spores} \cdot \mathrm{g}^{-1}$ $\mathrm{DM}$, which was 10 times higher than in a conventional tray reactor [159]. Several agricultural wastes such as rice husk, tea leaf waste, and wheat bran have revealed great sporulation of Beauveria bassiana in SSF that presents pathogenicity towards the larvae $M$. domestica [160].

Bacillus thuringiensis is a common producer of biopesticides releasing a crystalline protein known as $\delta$-endotoxin. Several studies compared the production of $\delta$-endotoxin by $B$. thuringiensis by SSF and SmF. Higher biomass production and induced early sporulation were achieved using several agricultural products. In addition, this process led to a reduction in the batch time for the economical production of biopesticides [161-163]. Zhuang et al. [164] demonstrated a cost-effective production of $B$. thuringiensis biopesticides using a mixture of waste water sludge and wheat bran by SSF that yielded a high number of viable cells $\left(5.98 \times 10^{10} \mathrm{CFU} \cdot \mathrm{g}^{-1}\right)$, spore counts $\left(5.26 \times 10^{10} \mathrm{CFU} \cdot \mathrm{g}^{-1}\right)$, toxin production $\left(7.14 \mathrm{mg} \cdot \mathrm{g}^{-1} \delta\right.$-endotoxin) and entomotoxicity $\left(4758 \mathrm{IU} \cdot \mathrm{mg}^{-1}\right)$. In other studies, kitchen 
waste $\left(5.01 \times 10^{10} \mathrm{CFU} \cdot \mathrm{g}^{-1} ; 15,200 \mathrm{IU} \cdot \mathrm{mg}^{-1}\right)$ was found to be efficient to produce $B$. thuringiensis biopesticides compared to conventional medium $\left(2.51 \times 10^{10} \mathrm{CFU} \cdot \mathrm{g}^{-1} ; 12,900 \mathrm{IU} \cdot \mathrm{mg}^{-1}\right)$ during $48 \mathrm{~h}$ of SSF. This study showed kitchen waste as an alternative medium to reduce production costs [165]. Utilization of soy fiber residue as substrate at lab scale for production of viable cells $\left(3.8 \times 10^{9} \mathrm{CFU} \cdot \mathrm{g}^{-1} \mathrm{DM}\right)$ and spores $\left(1.3 \times 10^{8}\right.$ spores $\left.\cdot \mathrm{g}^{-1} \mathrm{DM}\right)$ of $B$. thuringiensis under non-sterile condition eased the scale up to $10 \mathrm{~L}$ SSF reactors $\left(9.5 \times 10^{7} \mathrm{CFU} \cdot \mathrm{g}^{-1} \mathrm{DM} ; 1.1 \times 10^{8}\right.$ spores. $\left.\mathrm{g}^{-1} \mathrm{DM}\right)$ and substantially reduced the production costs and facilitated the waste management [166].

\subsection{Biosurfactant Production}

The production of biosurfactants during recent years has received great attention due to their eco-friendly features such as low toxicity, highly efficiency, and high biodegradability, contrary to the chemical synthesis of surfactants that mainly come from petroleum [167]. They are involved in various applications including environmental, food, household, agricultural, biomedical, cosmetics and the pharmaceutical industries. Since the emergence of biosurfactants, submerged fermentation has been a dominant research field in the manufacture of biosurfactants. However, during SmF, apart from having low yields and diluted product streams, severe foaming and a gradual increase in viscosity can occur [5]. The addition of chemical antifoams to overcome the problem implies a negative effect on the production of biosurfactants [168]. However, SSF can avoid the foaming problems during biosurfactant production, among other advantages such as low production costs, reduced waste water effluent, and no dilution problems.

Fungi, yeasts, and bacteria are able to produce biosurfactants (e.g., rhamnolipids, surfactin, sophorolipids, and peptidolipids) as secondary metabolites during their growth. Production of biosurfactants (surfactin and rhamnolipids) by Pleurotus djamor on sunflower seed shells as substrates supplemented with sunflower seed oil as carbon source has been reported under SSF [169]. A reduction in water surface tension from 72 to $29 \mathrm{mN} \cdot \mathrm{m}^{-1}$ with $10.2 \mathrm{~g} \cdot \mathrm{L}^{-1}$ of biosurfactants was produced. Also, their ability to remove $77 \%$ of waste frying oil from contaminated sand was demonstrated. A mixture of two by-products of olive mill factory (olive leaf residues and olive cake flour) was utilized as a substrate for Bacillus subtilis cultivation in SSF [170]. The results showed a potential to produce lipopeptides as $30.67 \mathrm{mg} \cdot \mathrm{g}^{-1}$ dry substrate within $48 \mathrm{~h}$, while at the same duration higher production of lipopeptides (50.01 mg.g ${ }^{-1}$ dry substrate) by Bacillus amyloliquefaciens on rice straw and soybean flour by SSF was obtained [171]. Additionally, in a 1000-fold scale up of surfactin production by B. amyloliquefaciens on rice straw and soybean mixtures reached $15.03 \mathrm{mg} \cdot \mathrm{g}^{-1}$ dry substrate [172], which was higher than the production by Bacillus pumilus in SSF using okara and sugarcane bagasse that yielded about $3.3 \mathrm{~g} \cdot \mathrm{kg}^{-1}$ dry substrate [173].

Various organic solid wastes can be utilized in SSF to produce diverse biosurfactants. For instance, soy processing waste cultivated with two different microorganisms showed that Candida guilliermondii produced a glycolipids complex while B. subtilis produced lipoprotein and glycolipids [174]. Also, B. subtilis was reported to yield lipopeptide biosurfactants when cultivated on potato peel from kitchen organic wastes [175]. Maximum yield of sophorolipids (18 g. $\mathrm{mg}^{-1}$ dry substrate) was attained by the cultivation of Starmerella bombicola on a mixture of wheat bran, glucose and oleic acid [176]. It was reported that by employing an intermittent mixing in SSF during the fermentation the production of sophorolipids increased in a 31\% [177]. Moreover, the cultivation of Pseudomonas aeruginosa on a mixture of sugarcane bagasse and corn bran supplemented with glycerol and soybean oil in SSF produced $45 \mathrm{~g} \cdot \mathrm{L}^{-1}$ of rhamnolipids [178].

In general, the utilization of low-cost materials such as solid organic wastes impregnated with appropriate carbon and nitrogen sources together with a suitable microorganism play a key factor towards efficient biosurfactant production by SSF. 


\subsection{Bioethanol Production}

Bioconversion of organic solid wastes instead of food source using SSF for bioethanol production is suitable and attractive for sustainability and renewable energy production. Several authors have proved the efficiency of SSF in the reduction of capital costs and consumption of energy and water during bioethanol production. The process also offers a valorization of organic solid wastes, the elimination of sugar extraction and additional separation steps, a production of higher yield and a simplification of the operation by carrying out the hydrolysis and the fermentation together.

Both yeast and fungi are the most reported microorganisms involved in bioethanol production due to their convenient environment in SSF. Saccharomyces cerevisiae yeast has been extensively reported as a responsible organism for the bioconversion of solid wastes (apple pomace, grape pomace, sugar beet pomace, potato peel, sweet sorghum stalks, sugarcane bagasse, food waste, etc.) into bioethanol production under SSF [54,179-183]. Du et al. [181] confirmed the feasibility of scaling up the bioconversion of sweet sorghum stalks by S. cerevisiae from $500 \mathrm{~mL}$ to a $127 \mathrm{~m}^{3}$ rotary drum fermenter and subsequently in a $550 \mathrm{~m}^{3}$ rotary drum fermenter with $88 \%$ of relative theoretical ethanol yield in less than $20 \mathrm{~h}$. Anjani et al. [180] presented an interesting integrated bioconversion of potato peel by SSF for the production of bioethanol and manure by employing yeast and fungi (Aspergillus niger, A. variabilis and S. cerevisiae) in an effort to achieve zero waste generation. In Asian regions, palm oil trunk [184], rice straw [185,186], and banana pseudo stem [187] were successfully utilized to produce bioethanol with high yield (84\%) by Aspergillus sp. and T. reesei through SSF.

Production of bioethanol in SSF has proved to achieve higher yields compared to SmF. For instance, the ethanol yield in a bioconversion of grape and sugar beet pomace was more than $82 \%$ obtained at $48 \mathrm{~h}$ and was higher than in liquid fermentations [179]. Also, the ethanol obtained was more concentrated than in SmF reducing the recovery costs. The utilization of the whole fermented medium containing an enzyme cocktail from Trichoderma reesei, A. niger, A. oryzae [188], and Kluveromyces marxianus [189] evidenced an efficient cost reduction by reducing enzyme extraction that enables the use of a single reactor system in SSF. Likewise, a consolidated bioprocess integrating enzyme production, saccharification, and fermentation for bioethanol production in SSF by Trichoderma sp., Penicillium sp., and S. cerevisiae avoided enzyme preparation, and reduced energy consumption and equipment investment [183].

Apart from yeast and fungi, other attempts have been made using bacterial strains to produce bioethanol that resulted in efficient bioconversion. In fact, an integrated bioconversion process of organic solid wastes (switchgrass and sweet sorghum bagasse) by Clostridium phytofermentans [190] and Zymomonas mobilis [191,192] competently resulted in a high bioethanol yield through SSF.

\subsection{Aroma Compounds Production}

There is a wide spectrum of application of aroma compounds in food, cosmetic, chemical, and pharmaceutical fields. Normally, aroma compounds have been produced by steam distillation and extraction of natural sources (e.g., plants, fruits, herbs, spices). Yet, the extraction of natural sources often gives various problems and low yields of the desired compounds that increase the downstream costs [193]. Although chemical synthesis may offer an economical price compared to natural extraction, environmental problems due to the manufacturing processes and the resolution of racemic mixtures are difficult to solve [194].

The range of aroma compounds such as fruit-like or flower-like depends largely on the strains and conditions [1]. Various fungi, yeast, and bacteria have the capability to produce aroma compounds such as Ceratocystis fimbriata, Aspergillus sp., Neurospora sp., Kluyveromyces marxianus, Bacillus subtilis, etc. [194]. The use of different yeast strains promotes the formation of the desired aroma compounds. Apple pomace inoculated with Saccharomyces cerevisiae, Hanseniaspora valbyensis, and Hanseniaspora uvarum indicated that a high level of fatty acids and their corresponding ethyl esters could be obtained with Saccharomyces strains. Also, substrate inoculated with Hanseniaspora sp. gave a high level of acetic esters and 132 volatile compounds belonging to different chemical families were 
identified by chromatographic analysis [195]. Apart from that, in the SSF process with food industry waste mixtures as a substrate for cultivation of $S$. cerevisiae, K. marxianus and kefir respectively, the production of $\varepsilon$-pinene was only observed as a product of kefir fermentation yielding a high amount (4208 $\mathrm{mg} \cdot \mathrm{kg}^{-1}$ of SSF product) [196]. Several authors have demonstrated the production of fruity aroma compounds by C. fimbriata in SSF using coffee residues (coffee husk, coffee pulp) as substrates [197,198]. Steam treated coffee husk is appropriate for aroma production by $C$. fimbriata supplemented with $20 \%$ of glucose concentration, while the addition of leucine improves the aroma intensity by $58 \%$, especially by increasing the ester production [199]. The production of fruity aroma compounds was increased $\left(99.60 \mu \mathrm{mol} \cdot \mathrm{g}^{-1}\right)$ using waste from citric juice production industry (citric pulp) cultivated with C. fimbriata by SSF supplemented with $50 \%$ of soya bran as a nitrogen source and $25 \%$ of sugarcane molasses as a carbon source [200]. This yield is higher than other ones reported in previous studies using other solid substrates [197]. The influence of oxygen on the total volatile compounds was demonstrated in studies carried out using cassava bagasse as a substrate for K. marxianus in SSF using packed bed reactors. Nine major fruity aroma compounds were identified, the lower aeration rates $\left(0.06 \mathrm{~L} \cdot \mathrm{h}^{-1} \cdot \mathrm{g}^{-1}\right.$ of initial dry matter) being responsible for an increase in total volatile compound production [201].

SSF has become a preferable method to produce aroma compounds as it can supply a natural condition for microbials to grow and also yields a higher concentration of aroma compounds compared to SmF. For instance, the production of 6-pentyl- $\alpha$-pyrone (6-PP), which is related to coconut smells, by Trichoderma sp. was compared in SSF and SmF. Sugarcane bagasse was used as a solid support for SSF reaching a higher yield of 6-PP concentration $\left(3.0 \pm 0.5 \mathrm{mg} \cdot \mathrm{g}^{-1} \mathrm{DM}\right)$ with no evidence of growth inhibition compared to that reported in the literature for $\mathrm{SmF}$ [202]. Other studies using T. viridae showed that increasing the concentration of sugarcane bagasse produced a significant increase in the 6-PP production $\left(3.62 \mathrm{mg} \cdot \mathrm{g}^{-1} \mathrm{DM}\right)$ after five days of fermentation. This production was higher than those reported in previous studies under the same fermentation conditions [203], whereas less 6-PP production by T. harzianum IOC 4042 using the same support was reported $\left(0.093 \mathrm{mg} \cdot \mathrm{g}^{-1} \mathrm{DM}\right)$ after seven days of fermentation [204]. Comparative analysis of production of aroma compounds by Pleurotus ostreatus JMO 95 fruit body and its mycelium obtained under SmF and SSF (agar and sugarcane bagasse) showed that the main aromatic compounds octan-3-one (sweet and fruity odor), octan-3-ol (hazelnut and sweet herbaceous odor) were produced in the same proportions on the agar surface and on the solid support culture. However, in liquid fermentation, the aromatic intensity produced was very low [205].The cultivation of P. ostreatus and Favolus tenuiculus by SSF using eucalyptus waste from the essential oil industry as a substrate was able to transform 1,8-cineole to new aroma compounds which were 1,3,3-trimethyl-2-oxabicyclo[2.2.2]octan-6-ol and 1,3,3-trimethyl-2-oxabicyclo[2.2.2] octan-6-one [206].

\section{Downstream Processing in SSF and Residue Reutilization}

Downstream processing is the processes involved after the fermentation process mainly bioseparations such as extraction, purification, and recovery. There are few studies reporting on downstream processing in SSF which hampers the process development in up-scaling. Not to mention the downstream processing that usually implies the need for additional processes and facilities that represent a cost up to $70 \%$ of production cost [207]. Since SSF is performed in limited or absence of liquid, an extraction with an appropriate solvent is necessary to recover secreted products that bind to the solid substrates. For this reason, extraction efficiency is crucial in order to obtain the maximum product-recovery from SSF. Dhillon et al. [208] achieved higher citric acid extraction from the SSF process using response surface methodology involving process parameters such as extraction time, agitation rate, and solvent volume. Solid-liquid ratio, solvent or buffer type, $\mathrm{pH}$, temperature, stirring rate, repeated extraction, and extraction time are process parameters that also have been studied to optimize the extraction of products from SSF [209-214]. However, in these studies usually a small amount of solid substrate ranging from 1-20 $\mathrm{g}$ in a shake flask was used for the extraction, and only 
some of them reported the extraction using the whole substrate fermented (in $\mathrm{kg}$ ) with the aim of knowing the total recovery of the product [20]. This assessment is considerably important since it affects the extraction efficiency and product recovery from SSF. To point out, it was reported in a scale up system, there was a reduction of product activity per gram of dry substrate of about $60 \%$ compared to the activity obtained at the lab scale, yet the total product activity obtained was high [215].

Szabo et al. [216] found that sonication has a significant effect on enzyme extraction. They observed that multiple extractions with sonication improved the recovery of enzymes from SSF with an increment of enzyme yield more than twice that of conventional single stage extraction. Furthermore, in order to improve the enzyme recovery from SSF, it has been observed that extraction followed by diafiltration can enhance the activity recovery by removing inhibitory phenolic compounds from extracts [217]. Since the recovery and concentration steps are significant in enzyme production, employing ultrafiltration with $10 \mathrm{kDa}$ cut off after solid-liquid extraction can improve the rate of enzyme recovery by about $74 \%[20,218]$. Moreover, the recovery of biosurfactant such as sophorolipid from SSF can be improved by employing solid-liquid extraction using methanol followed by multiple re-extractions of the fermented material with ethyl acetate with continuous mixing for $1 \mathrm{~h}$, subsequently filtered using $0.2 \mu \mathrm{m}$ membrane filtration [219]. The resulting crude extracts were further purified using a rotary evaporator at $40{ }^{\circ} \mathrm{C}$ to remove any solvent. Then, hexane was used to wash the remaining hydrophobic residue after vacuum drying and the partially purified sophorolipid was obtained after vaporizing the residual hexane at $40{ }^{\circ} \mathrm{C}$ under vacuum [220].

An innovation of downstream processing in SSF has been proposed using a simultaneous extraction and recovery of products scheme [207]. In this method, the enzyme was produced through SSF followed by a combined separation method (simultaneous extraction and recovery) based on aphron flotation. Briefly, the colloidal gas aphron (CGA) was generated by mixing solid biomass from SSF with distilled water and aluminum sulfate as a flocculating agent. Then the purified enzyme was recovered by filtration (Figure $2 b$ ). This method was considered straightforward by eliminating the extraction step in conventional SSF (Figure 2a) and producing a relatively pure enzyme. Furthermore, an efficient employment of single step aqueous two-phase extraction (ATPE) for downstream processing of enzyme produced from SSF (Figure 2c) has been reported, avoiding the conventional multi-step procedures involving salt precipitation, dialysis, and chromatography processes [221]. In addition, the high recovery of the enzyme within a short time $(3 \mathrm{~h})$ shows the potential commercial interest of this technique.

A novel simplified configuration for conversion of biomass to ethanol using the whole SSF cultivation medium for the hydrolysis of steam-exploded sugarcane bagasse [188]. This configuration would allow a single reactor system thus avoiding additional separation steps. The industrial production of biopolymers such as PHA (polyhydroxyalkanoate) are normally hampered by the high cost of production which involves capital investment in fermentation media and downstream processing. In this sense, SSF has been proposed as an alternative to SmF for more feasible PHA production using agro-industrial waste instead of using expensive defined media [93]. While in downstream processing an enzymatic method is more favorable compared to a chemical method due to the high recovery rate, the implementation has been limited by the high cost of the enzyme. A novel downstream separation processing using crude enzyme produced via SSF using sunflower meal as the main substrate has been proposed to reduce the high cost of PHA recovery [222]. The enzymatic lysis of bacterial cells facilitated a high recovery $(98 \%)$ and purity $(96.7 \%)$ of poly(3-hydroxybutyrate-co-3-hydroxyvalerate) showing that enzymatic digestion can be used as an alternative process to PHA recovery.

After the recovery of products, a solid waste with different level of biodegradability still remains once SSF processing is finished. Late work by our research group (data not published yet) indicates the possibility to reutilizing the remaining solid by composting and anaerobic digestion. The stabilization of the remaining organic matter was done by composting in the same reactors, and continuing the process until no increment in temperature was observed; the stability measured by means of the 
dynamic respiration index (DRI) was lower than $1 \mathrm{~g} \mathrm{O}_{2} \cdot \mathrm{kg}^{-1} \mathrm{OM} \cdot \mathrm{h}^{-1}$ [20]. Solid and liquid wastes generated after enzyme extraction of SSF during the ethanol fermentation process were reutilized as a substrate for anaerobic digestion to generate biogas in a zero waste approach [223]. Moreover, it has been observed that solid residues remained after production of citric acid in SSF can be reutilized in a sequential extraction process to produce fungal chitosan as an eco-friendly alternative to the chitosan derived from marine shells [224].

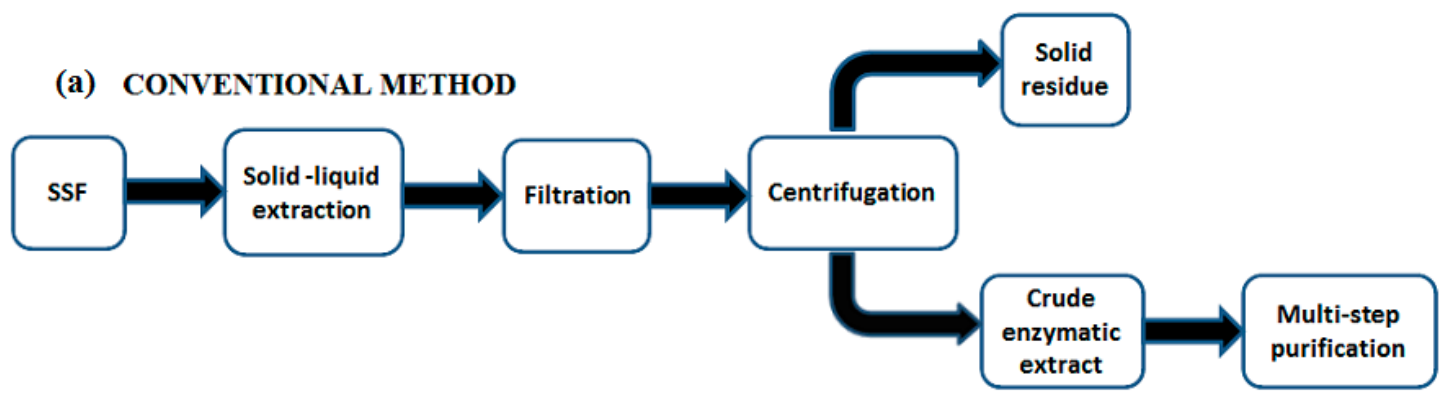

(b) SIMULTANEOUS EXTRACTION \& RECOVERY

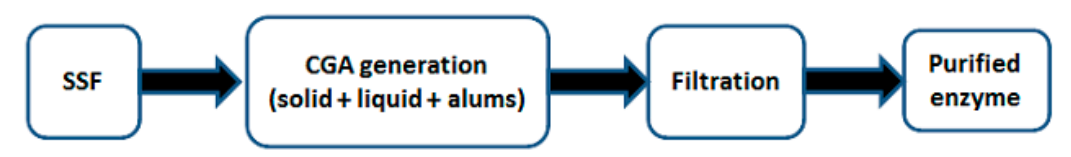

(c) SIMULTANEOUS PARTITIONING \& PURIFICATION

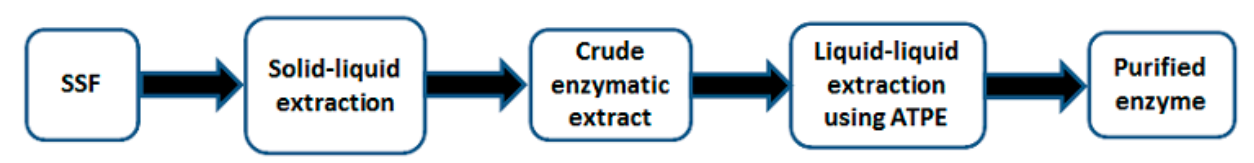

Figure 2. Schematic diagram of the downstream processing in SSF (a) conventional method; (b) simultaneous extraction and recovery based on aphron flotation; (c) simultaneous partitioning and purification using the ATPE system.

\section{Economic Viewpoint}

Solid state fermentation has proved to yield high biomolecules concentrations making further additional downstream processes easier than in SmF. Consequently, SSF minimized the requirements for additional equipment as well as energy and water consumption. Since the cost of substrates represents $30 \%-40 \%$ of total production costs [225], the valorization of organic solid waste as a substrate in SSF effectively reduces the operational costs. The superiority of SSF over SmF in several biotechnological processes poses an attractive economic feasibility. For instance, Zhuang et al. [226] compared an economic analysis of cellulase for bioethanol production through SSF and SmF. The analysis reported the unit costs for the cellulase production in SSF $\left(\$ 15.67 \mathrm{~kg} \cdot\right.$ cellulase $\left.^{-1}\right)$ and $\mathrm{SmF}\left(\$ 40.36 \mathrm{~kg} \cdot\right.$ cellulase $^{-1}$ ), while the market price for cellulase was approximate $\$ 90 \mathrm{~kg} \cdot$ cellulase $^{-1}$. Comparatively, a sensitivity analysis was performed indicating that the production cost using SSF was lower than $\mathrm{SmF}$ with an efficiency of $99.6 \%$. Furthermore, another report studied the economic analysis of hydrolases enzyme cocktails (amylase, cellulase, xylanase, protease) by A. awamori on babassu cake in SSF suggesting that solid residues or fermented cake generated after enzyme extraction can be sold as animal feed, which in turn compensates the enzyme production costs [227].

However, it does seem evident that there is an important lack of economical systematic studies on SSF economics, especially those related to the comparison between SSF and SmF. 


\section{Future Perspectives and Concluding Remarks}

The use of SSF in various biotechnological processes and in the production of value- added bio-products seems very appealing and promising as reported in this review. As SSF valorizes organic solid waste, it leads to the reduction of operational and production costs, concurrently contributes to solid waste management, and decreases environmental pollution. There are various types of organic solid waste that can be easily used and converted into valuable bio-products such as enzymes, organic acids, bioethanol, biopesticides, biosurfactants, etc. by means of SSF. Apart from these evident advantages, SSF presents limited application at industrial level due to several technical aspects that need to be improved and well established, such as scientific engineering and fermentation operational control. However, with the uprising of studies related to SSF that are being currently explored, it is believed that there are numerous aspects of bioreactor technology suitable to enhance processes to compensate for the lack of application at the industrial level. With the understanding of SSF theory and the development of current SSF technology for the production of biomolecules, SSF can be considered a novel paradigm for organic solid waste valorization.

Acknowledgments: The authors thank the Spanish Ministerio de Economia y Competitividad (Project CTM2015-69513-R) for their financial support. N.A. Yazid thanks the Government of Malaysia and University Malaysia Pahang for their financial support. Raquel Barrena is grateful to TECNIOspring fellowship programme (no. TECSPR15-1-0051) co-financed by the European Union through the Marie Curie Actions and Acció (Generalitat de Catalunya).

Author Contributions: Noraziah Abu Yazid and Antoni Sánchez conceived and designed the review; Raquel Barrena, Dimitrios Komilis, and Antoni Sánchez analyzed the data and revised the paper; Noraziah Abu Yazid wrote the paper draft.

Conflicts of Interest: The authors declare no conflict of interest. The funding sponsors had no role in the design of the study; in the collection, analyses, or interpretation of data; in the writing of the manuscript, and in the decision to publish the results.

\section{References}

1. Mussatto, S.I.; Ballesteros, L.F.; Martins, S.; Teixeira, J.A. Use of Agro-Industrial Wastes in Solid-State Fermentation Processes. In Industrial Waste; InTech: Rijeka, Croatia, 2012; pp. 121-141.

2. Eco-Cycle. Waste of Energy-Why Incineration Is Bad for Our Economy, Environment and Community; Eco-Cycle: Boulder County, CO, USA, 2011; pp. 1-20.

3. Sánchez, A.; Artola, A.; Font, X.; Gea, T.; Barrena, R.; Gabriel, D.; Sánchez-Monedero, M.Á.; Roig, A.; Cayuela, M.L.; Mondini, C. Greenhouse gas emissions from organic waste composting. Environ. Chem. Lett. 2015, 13, 223-238. [CrossRef]

4. Giuntini, E.; Bazzicalupo, M.; Castaldini, M.; Fabiani, A.; Miclaus, N.; Piccolo, R.; Ranalli, G.; Santomassimo, F.; Zanobini, S.; Mengoni, A. Genetic diversity of dinitrogen-fixing bacterial communities in soil amended with olive husks. Ann. Microbiol. 2006, 56, 83-88. [CrossRef]

5. Thomas, L.; Larroche, C.; Pandey, A. Current developments in solid-state fermentation. Biochem. Eng. J. 2013, 81, 146-161. [CrossRef]

6. Chen, H.Z.; He, Q. Value-added bioconversion of biomass by solid-state fermentation. J. Chem. Technol. Biotechnol. 2012, 87, 1619-1625. [CrossRef]

7. Pandey, A. Solid-state fermentation. Biochem. Eng. J. 2003, 13, 81-84. [CrossRef]

8. Hölker, U.; Lenz, J. Solid-state fermentation-Are there any biotechnological advantages? Curr. Opin. Microbiol. 2005, 8, 301-306. [CrossRef] [PubMed]

9. Pandey, A.; Soccol, C.R.; Mitchell, D. New developments in solid state fermentation: I-bioprocesses and products. Process Biochem. 2000, 35, 1153-1169. [CrossRef]

10. Wang, L.; Yang, S.-T. Chapter 18-Solid State Fermentation and Its Applications. In Bioprocessing for Value-Added Products from Renewable Resources: New Technologies and Applications; Elsevier B.V.: Amsterdam, The Netherlands, 2007; pp. 465-489.

11. Singhania, R.R.; Patel, A.K.; Soccol, C.R.; Pandey, A. Recent advances in solid-state fermentation. Biochem. Eng. J. 2009, 44, 13-18. [CrossRef] 
12. El-Bakry, M.; Abraham, J.; Cerda, A.; Barrena, R.; Ponsá, S.; Gea, T.; Sánchez, A. From Wastes to High Value Added Products: Novel Aspects of SSF in the Production of Enzymes. Crit. Rev. Environ. Sci. Technol. 2015, 45, 1999-2042. [CrossRef]

13. Dave, B.R.; Sudhir, A.P.; Pansuriya, M.; Raykundaliya, D.P.; Subramanian, R.B. Utilization of Jatropha deoiled seed cake for production of cellulases under solid-state fermentation. Bioprocess Biosyst. Eng. 2012, 35, 1343-1353. [CrossRef] [PubMed]

14. Motta, F.L.; Santana, M.H. Solid-state fermentation for humic acids production by a Trichoderma reesei strain using an oil palm empty fruit bunch as the substrate. Appl. Biochem. Biotechnol. 2014, 172, 2205-2217. [CrossRef] [PubMed]

15. Ohkouchi, Y.; Inoue, Y. Impact of chemical components of organic wastes on 1(+)-lactic acid production. Bioresour. Technol. 2007, 98, 546-553. [CrossRef] [PubMed]

16. Zhang, W.; Zou, H.; Jiang, L.; Yao, J.; Liang, J.; Wang, Q. Semi-solid state fermentation of food waste for production of Bacillus thuringiensis biopesticide. Biotechnol. Bioprocess Eng. 2015, 20, 1123-1132. [CrossRef]

17. Jooste, T.; García-Aparicio, M.P.; Brienzo, M.; Van Zyl, W.H.; Görgens, J.F. Enzymatic hydrolysis of spent coffee ground. Appl. Biochem. Biotechnol. 2013, 169, 2248-2262. [CrossRef] [PubMed]

18. Rocha, M.V.P.; de Matos, L.J.B.L.; De Lima, L.P.; Figueiredo, P.M.D.S.; Lucena, I.L.; Fernandes, F.A.N.; Gonçalves, L.R.B. Ultrasound-assisted production of biodiesel and ethanol from spent coffee grounds. Bioresour. Technol. 2014, 167, 343-348. [CrossRef] [PubMed]

19. Abraham, J.; Gea, T.; Sánchez, A. Substitution of chemical dehairing by proteases from solid-state fermentation of hair wastes. J. Clean. Prod. 2014, 74, 191-198. [CrossRef]

20. Yazid, N.A.; Barrena, R.; Sánchez, A. Assessment of protease activity in hydrolysed extracts from SSF of hair waste by and indigenous consortium of microorganisms. Waste Manag. 2016, 49, 420-426. [CrossRef] [PubMed]

21. Wiradimadja, R.; Rusmana, D.; Widjastuti, T.; Mushawwir, A. Chicken Slaughterhouse Waste Utilization (Chicken Feather Meal Treated) as a Source of Protein Animal Feed Ingredients in Broiler Chickens. Lucr. Stiint.-Ser. Zooteh. 2014, 62, 120-124.

22. Kanagaraj, J.; Velappan, K.C.; Chandra Babu, N.K.; Sadulla, S. Solid wastes generation in the leather industry and its utilization for cleaner environment-A review. J. Sci. Ind. Res. (India) 2006, 65, 541-548.

23. Rathna, G.S.; Saranya, R.; Kalaiselvam, M. Original Research Article Bioethanol from sawdust using cellulase hydrolysis of Aspergillus ochraceus and fermentation by Saccharomyces cerevisiae. Int. J. Curr. Microbiol. Appl. Sci. 2014, 3, 733-742.

24. Ghazi, I.; Fernandez-Arrojo, L.; Gomez De Segura, A.; Alcalde, M.; Plou, F.J.; Ballesteros, A. Beet sugar syrup and molasses as low-cost feedstock for the enzymatic production of fructo-oligosaccharides. J. Agric. Food Chem. 2006, 54, 2964-2968. [CrossRef] [PubMed]

25. Jayathilakan, K.; Sultana, K.; Radhakrishna, K.; Bawa, A.S. Utilization of byproducts and waste materials from meat, poultry and fish processing industries: A review. J. Food Sci. Technol. 2012, 49, 278-293. [CrossRef] [PubMed]

26. Kim, S.K.; Mendis, E. Bioactive compounds from marine processing byproducts-A review. Food Res. Int. 2006, 39, 383-393. [CrossRef]

27. Kandra, P.; Challa, M.M.; Kalangi Padma Jyothi, H. Efficient use of shrimp waste: Present and future trends. Appl. Microbiol. Biotechnol. 2012, 93, 17-29. [CrossRef] [PubMed]

28. Elmekawy, A.; Diels, L.; De Wever, H.; Pant, D. Valorization of cereal based biorefinery byproducts: Reality and expectations. Environ. Sci. Technol. 2013, 47, 9014-9027. [CrossRef] [PubMed]

29. Embaby, A.M.; Masoud, A.A.; Marey, H.S.; Shaban, N.Z.; Ghonaim, T.M. Raw agro-industrial orange peel waste as a low cost effective inducer for alkaline polygalacturonase production from Bacillus licheniformis SHG10. Springerplus 2014, 3, 327-340. [CrossRef] [PubMed]

30. Panda, S.K.; Mishra, S.S.; Kayitesi, E.; Ray, R.C. Microbial-processing of fruit and vegetable wastes for production of vital enzymes and organic acids: Biotechnology and scopes. Environ. Res. 2016, 146, 161-172. [CrossRef] [PubMed]

31. Mtui, G.Y.S. Recent advances in pretreatment of lignocellulosic wastes and production of value added products. Afr. J. Biotechnol. 2009, 8, 1398-1415. 
32. Govumoni, S.P.; Gentela, J.; Koti, S.; Haragopal, V.; Venkateshwar, S.; Rao, L.V. Original Research Article Extracellular Lignocellulolytic Enzymes by Phanerochaete chrysosporium (MTCC 787) Under Solid-State Fermentation of Agro Wastes. Int. J. Curr. Microbiol. Appl. Sci. 2015, 4, 700-710.

33. Ukpai, P.A.; Nnabuchi, M.N. Comparative study of biogas production from cow dung, cow pea and cassava peeling using 45 litres biogas digester. Adv. Appl. Sci. Res. 2012, 3, 1864-1869.

34. Sebola, M.R.; Tesfagiorgis, H.B.; Muzenda, E. Methane Production from Anaerobic Co-digestion of Cow Dung, Chicken Manure, Pig Manure and Sewage Waste. In Proceedings of the World Congress on Engineering, London, UK, 1-3 July 2015; Volume I, pp. 1-7.

35. Adams, T.T.; Eiteman, M.A.; Hanel, B.M. Solid state fermentation of broiler litter for production of biocontrol agents. Bioresour. Technol. 2002, 82, 33-41. [CrossRef]

36. Botella, C.; Diaz, A.; de Ory, I.; Webb, C.; Blandino, A. Xylanase and pectinase production by Aspergillus awamori on grape pomace in solid state fermentation. Process Biochem. 2007, 42, 98-101. [CrossRef]

37. Jørgensen, H.; Sanadi, A.R.; Felby, C.; Lange, N.E.K.; Fischer, M.; Ernst, S. Production of ethanol and feed by high dry matter hydrolysis and fermentation of Palm kernel press cake. Appl. Biochem. Biotechnol. 2010, 161, 318-332. [CrossRef] [PubMed]

38. Gratuito, M.K.B.; Panyathanmaporn, T.; Chumnanklang, R.A.; Sirinuntawittaya, N.; Dutta, A. Production of activated carbon from coconut shell: Optimization using response surface methodology. Bioresour. Technol. 2008, 99, 4887-4895. [CrossRef] [PubMed]

39. Sapuan, S.M.; Harimi, M.; Maleque, M.A. Mechanical Properties of Epoxy/Coconut Shell Filler Particle Composites. Arab. J. Sci. Eng. 2003, 28, 171-181.

40. Sunil, K.S.; Vinay, D.R.; Saviraj, A.S.; Naik, P.K. Flexural Behaviour of Coconut Shell/Epoxy Composites Subjected to Accelerated Ageing. Am. J. Mater. Sci. 2015, 5, 126-132.

41. Behera, S.S.; Ray, R.C. Solid state fermentation for production of microbial cellulases: Recent advances and improvement strategies. Int. J. Biol. Macromol. 2016, 86, 656-669. [CrossRef] [PubMed]

42. De Castro, R.J.S.; Ohara, A.; Nishide, T.G.; Bagagli, M.P.; Gonçalves Dias, F.F.; Sato, H.H. A versatile system based on substrate formulation using agroindustrial wastes for protease production by Aspergillus niger under solid state fermentation. Biocatal. Agric. Biotechnol. 2015, 4, 678-684. [CrossRef]

43. Do-Myoung, K.; Eun, J.C.; Ji, W.K.; Yong-Woog, L.; Hwa-Jee, C. Production of cellulases by Penicillium sp. in a solid-state fermentation of oil palm empty fruit bunch. Afr. J. Biotechnol. 2014, 13, 145-155.

44. Mehboob, N.; Asad, M.J.; Imran, M.; Gulfraz, M.; Wattoo, F.H.; Hadri, S.H.; Asghar, M. Production of lignin peroxidase by Ganoderma leucidum using solid state fermentation. Afr. J. Biotechnol. 2011, 10, 9880-9887.

45. Graminha, E.B.N.; Gonçalves, A.Z.L.; Pirota, R.D.P.B.; Balsalobre, M.A.A.; Da Silva, R.; Gomes, E. Enzyme production by solid-state fermentation: Application to animal nutrition. Anim. Feed Sci. Technol. 2008, 144, 1-22. [CrossRef]

46. Chang, J.; Cheng, W.; Yin, Q.; Zuo, R.; Song, A.; Zheng, Q.; Wang, P.; Wang, X.; Liu, J. Effect of steam explosion and microbial fermentation on cellulose and lignin degradation of corn stover. Bioresour. Technol. 2012, 104, 587-592. [CrossRef] [PubMed]

47. Lio, J.; Wang, T. Solid-state fermentation of soybean and corn processing coproducts for potential feed improvement. J. Agric. Food Chem. 2012, 60, 7702-7709. [CrossRef] [PubMed]

48. Nguyen, M.V.; Lee, B.K. Removal of dimethyl sulfide from aqueous solution using cost-effective modified chicken manure biochar produced from slow pyrolysis. Sustainability 2015, 7, 15057-15072. [CrossRef]

49. Demiral, H.; Demiral, İ. Surface properties of activated carbon prepared from wastes. Surf. Interface Anal. 2008, 40, 612-615. [CrossRef]

50. Liu, H.; Chen, D.; Zhang, R.; Hang, X.; Li, R.; Shen, Q. Amino Acids Hydrolyzed from Animal Carcasses Are a Good Additive for the Production of Bio-organic Fertilizer. Front. Microbiol. 2016, 7, 1-10. [CrossRef] [PubMed]

51. Daâssi, D.; Zouari-Mechichi, H.; Frikha, F.; Rodríguez-Couto, S.; Nasri, M.; Mechichi, T. Sawdust waste as a low-cost support-substrate for laccases production and adsorbent for azo dyes decolorization. J. Environ. Heal. Sci. Eng. 2016, 14, 1-12. [CrossRef] [PubMed]

52. Ravindran, B.; Kumar, A.G.; Bhavani, P.S.A.; Sekaran, G. Solid-state fermentation for the production of alkaline protease by Bacillus cereus 1173900 using proteinaceous tannery solid waste. Current 2011, 100, 726-730. 
53. Veana, F.; Martínez-Hernández, J.L.; Aguilar, C.N.; Rodríguez-Herrera, R.; Michelena, G. Utilization of molasses and sugar cane bagasse for production of fungal invertase in solid state fermentation using Aspergillus niger GH1. Braz. J. Microbiol. 2014, 45, 373-377. [CrossRef] [PubMed]

54. Kanwar, S.; Kumar, G.; Sahgal, M.; Singh, A. Ethanol Production through Saccharomyces Based Fermentation Using Apple Pomace Amended with Molasses. Sugar Tech. 2012, 14, 304-311. [CrossRef]

55. Sathiyanarayanan, G.; Kiran, G.S.; Selvin, J.; Saibaba, G. Optimization of polyhydroxybutyrate production by marine Bacillus megaterium MSBN04 under solid state culture. Int. J. Biol. Macromol. 2013, 60, 253-261. [CrossRef] [PubMed]

56. Mandalari, G.; Bisignano, G.; Lo Curto, R.B.; Waldron, K.W.; Faulds, C.B. Production of feruloyl esterases and xylanases by Talaromyces stipitatus and Humicola grisea var. thermoidea on industrial food processing by-products. Bioresour. Technol. 2008, 99, 5130-5133. [PubMed]

57. Singh, A.; Kuila, A.; Adak, S.; Bishai, M.; Banerjee, R. Utilization of Vegetable Wastes for Bioenergy Generation. Agric. Res. 2012, 1, 213-222. [CrossRef]

58. Suresh, P.V.; Anil Kumar, P.K. Enhanced degradation of a-chitin materials prepared from shrimp processing byproduct and production of $N$-acetyl-D-glucosamine by thermoactive chitinases from soil mesophilic fungi. Biodegradation 2012, 23, 597-607. [CrossRef] [PubMed]

59. Nidheesh, T.; Pal, G.K.; Suresh, P.V. Chitooligomers preparation by chitosanase produced under solid state fermentation using shrimp by-products as substrate. Carbohydr. Polym. 2015, 121, 1-9. [CrossRef] [PubMed]

60. Esakkiraj, P.; Usha, R.; Palavesam, A.; Immanuel, G. Solid-state production of esterase using fish processing wastes by Bacillus altitudinis AP-MSU. Food Bioprod. Process. 2012, 90, 370-376. [CrossRef]

61. Uçkun Kiran, E.; Trzcinski, A.P.; Liu, Y. Glucoamylase production from food waste by solid state fermentation and its evaluation in the hydrolysis of domestic food waste. Biofuel Res. J. 2014, 3, 98-105. [CrossRef]

62. Melikoglu, M.; Lin, C.S.K.; Webb, C. Solid state fermentation of waste bread pieces by Aspergillus awamori: Analysing the effects of airflow rate on enzyme production in packed bed bioreactors. Food Bioprod. Process. 2015, 95, 63-75. [CrossRef]

63. Cerda, A.; El-Bakry, M.; Gea, T.; Sánchez, A. Long term enhanced solid-state fermentation: Inoculation strategies for amylase production from soy and bread wastes by Thermomyces sp. in a sequential batch operation. J. Environ. Chem. Eng. 2016, 4, 2394-2401. [CrossRef]

64. Janveja, C.; Rana, S.S.; Soni, S.K. Optimization of valorization of biodegradable kitchen waste biomass for production of fungal cellulase system by statistical modeling. Waste Biomass Valoriz. 2014, 5, 807-821. [CrossRef]

65. Abdullah, J.J.; Greetham, D.; Pensupa, N.; Tucker, G.A.; Du, C. Optimizing Cellulase Production from Municipal Solid Waste (MSW) using Solid State Fermentation (SSF). J. Fundam. Renew. Energy Appl. 2016, 6, 206. [CrossRef]

66. Mantzouridou, F.T.; Paraskevopoulou, A.; Lalou, S. Yeast flavour production by solid state fermentation of orange peel waste. Biochem. Eng. J. 2015, 101, 1-8. [CrossRef]

67. Matsakas, L.; Kekos, D.; Loizidou, M.; Christakopoulos, P. Utilization of household food waste for the production of ethanol at high dry material content. Biotechnol. Biofuels 2014, 7, 4-13. [CrossRef] [PubMed]

68. Matsakas, L.; Christakopoulos, P. Ethanol production from enzymatically treated dried food waste using enzymes produced on-site. Sustainability 2015, 7, 1446-1458. [CrossRef]

69. Sun, Z.; Li, M.; Qi, Q.; Gao, C.; Lin, C.S.K. Mixed Food Waste as Renewable Feedstock in Succinic Acid Fermentation. Appl. Biochem. Biotechnol. 2014, 174, 1822-1833. [CrossRef] [PubMed]

70. Ezejiofor, T.I.N.; Duru, C.I.; Asagbra, A.E.; Ezejiofor, A.N.; Orisakwe, O.E.; Afonne, J.O.; Obi, E. Waste to wealth: Production of oxytetracycline using streptomyces species from household kitchen wastes of agricultural produce. Afr. J. Biotechnol. 2012, 11, 10115-10124.

71. López-Pérez, M.; Viniegra-González, G. Production of protein and metabolites by yeast grown in solid state fermentation: Present status and perspectives. J. Chem. Technol. Biotechnol. 2016, 91, 1224-1231. [CrossRef]

72. Martins, S.; Mussatto, S.I.; Martínez-Avila, G.; Montañez-Saenz, J.; Aguilar, C.N.; Teixeira, J.A. Bioactive phenolic compounds: Production and extraction by solid-state fermentation. A review. Biotechnol. Adv. 2011, 29, 365-373. [CrossRef] [PubMed]

73. Liu, D.; Zhang, R.; Yang, X.; Wu, H.; Xu, D.; Tang, Z.; Shen, Q. Thermostable cellulase production of Aspergillus fumigatus Z5 under solid-state fermentation and its application in degradation of agricultural wastes. Int. Biodeterior. Biodegrad. 2011, 65, 717-725. [CrossRef] 
74. Ávila-Cisneros, N.; Velasco-Lozano, S.; Huerta-Ochoa, S.; Córdova-López, J.; Gimeno, M.; Favela-Torres, E. Production of Thermostable Lipase by Thermomyces lanuginosus on Solid-State Fermentation: Selective Hydrolysis of Sardine Oil. Appl. Biochem. Biotechnol. 2014, 174, 1859-1872. [CrossRef] [PubMed]

75. Saqib, A.A.N.; Farooq, A.; Iqbal, M.; Hassan, J.U.; Hayat, U.; Baig, S. A thermostable crude endoglucanase produced by aspergillus fumigatus in a novel solid state fermentation process using isolated free water. Enzyme Res. 2012, 2012, 1-6. [CrossRef] [PubMed]

76. Tsegaye, K.N.; Gessesse, A. Amylase production under solid state fermentation by a bacterial isolate W74. Afr. J. Biotechnol. 2014, 13, 2145-2153.

77. Afrisham, S.; Badoei-Dalfard, A.; Namaki-Shoushtari, A.; Karami, Z. Characterization of a thermostable, $\mathrm{CaCl}$-activated and raw-starch hydrolyzing alpha-amylase from Bacillus licheniformis AT70: Production under solid state fermentation by utilizing agricultural wastes. J. Mol. Catal. B Enzym. 2016, 132, 98-106. [CrossRef]

78. Özdemir, S.; Matpan, F.; Okumus, V.; Dündar, A.; Ulutas, M.S.; Kumru, M. Isolation of a thermophilic Anoxybacillus flavithermus sp. nov. and production of thermostable $\alpha$-amylase under solid-state fermentation (SSF). Ann. Microbiol. 2012, 62, 1367-1375.

79. Prajapati, V.S.; Trivedi, U.B.; Patel, K.C. A statistical approach for the production of thermostable and alklophilic alpha-amylase from Bacillus amyloliquefaciens KCP2 under solid-state fermentation. 3 Biotech 2015, 5, 211-220. [CrossRef]

80. Das, R.K.; Brar, S.K.; Verma, M. Potential use of pulp and paper solid waste for the bio-production of fumaric acid through submerged and solid state fermentation. J. Clean. Prod. 2016, 112, 4435-4444. [CrossRef]

81. Bhalkar, B.N.; Bedekar, P.A.; Kshirsagar, S.D.; Govindwar, S.P. Solid state fermentation of soybean waste and an up-flow column bioreactor for continuous production of camptothecine by an endophytic fungus: Fusarium oxysporum. RSC Adv. 2016, 6, 56527-56536. [CrossRef]

82. De Castro, R.J.S.; Sato, H.H. Enzyme Production by Solid State Fermentation: General Aspects and an Analysis of the Physicochemical Characteristics of Substrates for Agro-industrial Wastes Valorization. Waste Biomass Valoriz. 2015, 6, 1085-1093. [CrossRef]

83. Orzua, M.C.; Mussatto, S.I.; Contreras-Esquivel, J.C.; Rodriguez, R.; de la Garza, H.; Teixeira, J.A.; Aguilar, C.N. Exploitation of agro industrial wastes as immobilization carrier for solid-state fermentation. Ind. Crops Prod. 2009, 30, 24-27. [CrossRef]

84. Abraham, J.; Gea, T.; Sánchez, A. Potential of the solid-state fermentation of soy fiber residues by native microbial populations for bench-scale alkaline protease production. Biochem. Eng. J. 2013, 74, 15-19. [CrossRef]

85. Viniegra-González, G.; Favela-Torres, E.; Aguilar, C.N.; Rómero-Gomez, S.D.J.; Díaz-Godínez, G.; Augur, C. Advantages of fungal enzyme production in solid state over liquid fermentation systems. Biochem. Eng. J. 2003, 13, 157-167. [CrossRef]

86. Hölker, U.; Höfer, M.; Lenz, J. Biotechnological advantages of laboratory-scale solid-state fermentation with fungi. Appl. Microbiol. Biotechnol. 2004, 64, 175-186. [CrossRef] [PubMed]

87. Gabelle, J.C.; Jourdier, E.; Licht, R.B.; Ben Chaabane, F.; Henaut, I.; Morchain, J.; Augier, F. Impact of rheology on the mass transfer coefficient during the growth phase of Trichoderma reesei in stirred bioreactors. Chem. Eng. Sci. 2012, 75, 408-417. [CrossRef]

88. De la Cruz Quiroz, R.; Roussos, S.; Hernández, D.; Rodríguez, R.; Castillo, F.; Aguilar, C.N. Challenges and opportunities of the bio-pesticides production by solid-state fermentation: Filamentous fungi as a model. Crit. Rev. Biotechnol. 2015, 35, 326-333. [CrossRef] [PubMed]

89. Hongzhang, C.; Hongqiang, L.; Liying, L. The inhomogeneity of corn stover and its effects on bioconversion. Biomass Bioenergy 2011, 35, 1940-1945. [CrossRef]

90. Raghavarao, K.S.M.; Ranganathan, T.; Karanth, N. Some engineering aspects of solid-state fermentation. Biochem. Eng. J. 2003, 13, 127-135. [CrossRef]

91. Mansour, A.A.; Arnaud, T.; Lu-Chau, T.A.; Fdz-Polanco, M.; Moreira, M.T.; Rivero, J.A.C. Review of solid state fermentation for lignocellulolytic enzyme production: Challenges for environmental applications. Rev. Environ. Sci. Biotechnol. 2016, 15, 31-46. [CrossRef]

92. Rahardjo, Y.S.P.; Korona, D.; Haemers, S.; Weber, F.J.; Tramper, J.; Rinzema, A. Limitations of membrane cultures as a model solid-state fermentation system. Lett. Appl. Microbiol. 2004, 39, 504-508. [CrossRef] [PubMed] 
93. Sindhu, R.; Pandey, A.; Binod, P. Solid-state Fermentation for the Production of Poly(hydroxyalkanoates). Chem. Biochem. Eng. Q. 2015, 29, 173-181. [CrossRef]

94. Ortiz, G.E.; Guitart, M.E.; Cavalitto, S.F.; Albertó, E.O.; Fernández-Lahore, M.; Blasco, M. Characterization, optimization, and scale-up of cellulases production by trichoderma reesei cbs 836.91 in solid-state fermentation using agro-industrial products. Bioprocess Biosyst. Eng. 2015, 38, 2117-2128. [PubMed]

95. Salihu, A.; Sallau, A.B.; Adamu, A.; Kudu, F.A.; Tajo, M.M.; Bala, T.F.; Yashim, W.D. Utilization of Groundnut Husk as a Solid Substrate for Cellulase Production by Aspergillus niger Using Response Surface Methodology. Waste Biomass Valoriz. 2014, 5, 585-593. [CrossRef]

96. Sun, H.-Y.; Li, J.; Zhao, P.; Peng, M. Banana peel: A novel substrate for cellulase production under solid-state fermentation. Afr. J. Biotechnol. 2011, 10, 17887-17890.

97. Zhou, H.; Wang, C.Z.; Ye, J.Z.; Chen, H.X.; Tao, R.; Zhang, Y.S. Solid-state fermentation of Ginkgo biloba L. residue for optimal production of cellulase, protease and the simultaneous detoxification of Ginkgo biloba $\mathrm{L}$. residue using Candida tropicalis and Aspergillus oryzae. Eur. Food Res. Technol. 2015, 240, 379-388.

98. Bansal, N.; Janveja, C.; Tewari, R.; Soni, R.; Soni, S.K. Highly thermostable and pH-stable cellulases from Aspergillus niger NS-2: Properties and application for cellulose hydrolysis. Appl. Biochem. Biotechnol. 2014, 172, 141-156. [CrossRef] [PubMed]

99. Dave, B.R.; Parmar, P.; Sudhir, A.; Singal, N.; Subramanian, R.B. Cellulases production under solid state fermentation using agro waste as a substrate and its application in saccharification by Trametes hirsuta NCIM. J. Microbiol. Biotechnol. Food Sci. 2015, 4, 203-208. [CrossRef]

100. Gasparotto, J.M.; Werle, L.B.; Foletto, E.L.; Kuhn, R.C.; Jahn, S.L.; Mazutti, M.A. Production of Cellulolytic Enzymes and Application of Crude Enzymatic Extract for Saccharification of Lignocellulosic Biomass. Appl. Biochem. Biotechnol. 2015, 175, 560-572. [CrossRef] [PubMed]

101. Pathak, P.; Bhardwaj, N.K.; Singh, A.K. Production of crude cellulase and xylanase from Trichoderma harzianum PPDDN10 NFCCI-2925 and its application in photocopier waste paper recycling. Appl. Biochem. Biotechnol. 2014, 172, 3776-3797. [CrossRef] [PubMed]

102. Raghuwanshi, S.; Deswal, D.; Karp, M.; Kuhad, R.C. Bioprocessing of enhanced cellulase production from a mutant of Trichoderma asperellum RCK2011 and its application in hydrolysis of cellulose. Fuel 2014, 124, 183-189. [CrossRef]

103. Sandhu, S.K.; Oberoi, H.S.; Babbar, N.; Miglani, K.; Chadha, B.S.; Nanda, D.K. Two-Stage Statistical Medium Optimization for Augmented Cellulase Production via Solid-State Fermentation by Newly Isolated Aspergillus niger HN-1 and Application of Crude Cellulase Consortium in Hydrolysis of Rice Straw. J. Agric. Food Chem. 2013, 61, 12653-12661. [CrossRef] [PubMed]

104. Saratale, G.D.; Kshirsagar, S.D.; Sampange, V.T.; Saratale, R.G.; Oh, S.E.; Govindwar, S.P.; Oh, M.K. Cellulolytic Enzymes Production by Utilizing Agricultural Wastes Under Solid State Fermentation and its Application for Biohydrogen Production. Appl. Biochem. Biotechnol. 2014, 174, 2801-2817. [CrossRef] [PubMed]

105. Kumar, A.; Dutt, D.; Gautam, A. Production of crude enzyme from Aspergillus nidulans AKB-25 using black gram residue as the substrate and its industrial applications. J. Genet. Eng. Biotechnol. 2016, 14, 107-118. [CrossRef]

106. Anto, H.; Trivedi, U.B.; Patel, K.C. Glucoamylase production by solid-state fermentation using rice flake manufacturing waste products as substrate. Bioresour. Technol. 2006, 97, 1161-1166. [CrossRef] [PubMed]

107. Melikoglu, M.; Lin, C.S.K.; Webb, C. Stepwise optimisation of enzyme production in solid state fermentation of waste bread pieces. Food Bioprod. Process. 2013, 91, 638-646. [CrossRef]

108. Saxena, R.; Singh, R. Amylase production by solid-state fermentation of agro-industrial wastes using Bacillus sp. Braz. J. Microbiol. 2011, 42, 1334-1342. [CrossRef] [PubMed]

109. Pandi, A.; Ramalingam, S.; Rao, R. Inexpensive $\alpha$-amylase production and application for fiber splitting in leather processing. RSC Adv. 2016, 6, 33170-33176. [CrossRef]

110. Singh, S.; Singh, S.; Bali, V.; Sharma, L.; Mangla, J. Production of fungal amylases using cheap, readily available agriresidues, for potential application in textile industry. BioMed Res. Int. 2014, 2014, 1-9. [CrossRef] [PubMed]

111. De Castro, R.J.S.; Sato, H.H. Production and biochemical characterization of protease from Aspergillus oryzae: An evaluation of the physical-chemical parameters using agroindustrial wastes as supports. Biocatal. Agric. Biotechnol. 2014, 3, 20-25. [CrossRef] 
112. Mahanta, N.; Gupta, A.; Khare, S.K. Production of protease and lipase by solvent tolerant Pseudomonas aeruginosa PseA in solid-state fermentation using Jatropha curcas seed cake as substrate. Bioresour. Technol. 2008, 99, 1729-1735. [CrossRef] [PubMed]

113. Novelli, P.K.; Barros, M.M.; Fleuri, L.F. Novel inexpensive fungi proteases: Production by solid state fermentation and characterization. Food Chem. 2016, 198, 119-124. [CrossRef] [PubMed]

114. Prakasham, R.S.; Rao, C.S.; Sarma, P.N. Green gram husk-an inexpensive substrate for alkaline protease production by Bacillus sp. in solid-state fermentation. Bioresour. Technol. 2006, 97, 1449-1454. [PubMed]

115. Da Silva, R.R.; de Freitas Cabral, T.P.; Rodrigues, A.; Cabral, H. Production and partial characterization of serine and metallo peptidases secreted by Aspergillus fumigatus Fresenius in submerged and solid state fermentation. Braz. J. Microbiol. 2013, 44, 235-243. [CrossRef] [PubMed]

116. Vijayaraghavan, P.; Lazarus, S.; Vincent, S.G.P. De-hairing protease production by an isolated Bacillus cereus strain AT under solid-state fermentation using cow dung: Biosynthesis and properties. Saudi J. Biol. Sci. 2014, 21, 27-34. [CrossRef] [PubMed]

117. El-Bakry, M.; Gea, T.; Sánchez, A. Inoculation effect of thermophilic microorganisms on protease production through solid-state fermentation under non-sterile conditions at lab and bench scale (SSF). Bioprocess Biosyst. Eng. 2016, 39, 585-592. [CrossRef] [PubMed]

118. Verma, A.; Ansari, M.W.; Anwar, M.S.; Agrawal, R.; Agrawal, S. Alkaline protease from Thermoactinomyces sp. RS1 mitigates industrial pollution. Protoplasma 2014, 251, 711-718. [PubMed]

119. Paul, T.; Das, A.; Mandal, A.; Jana, A.; Maity, C.; Adak, A.; Halder, S.K.; DasMohapatra, P.K.; Pati, B.R.; Mondal, K.C. Effective dehairing properties of keratinase from Paenibacillus woosongensis TKB2 obtained under solid state fermentation. Waste Biomass Valoriz. 2014, 5, 97-107. [CrossRef]

120. Santis-Navarro, A.; Gea, T.; Barrena, R.; Sánchez, A. Production of lipases by solid state fermentation using vegetable oil-refining wastes. Bioresour. Technol. 2011, 102, 10080-10084. [CrossRef] [PubMed]

121. Silveira, E.A.; Tardioli, P.W.; Farinas, C.S. Valorization of Palm Oil Industrial Waste as Feedstock for Lipase Production. Appl. Biochem. Biotechnol. 2016, 179, 558-571. [CrossRef] [PubMed]

122. Herculano, P.N.; Moreira, K.A.; Bezerra, R.P.; Porto, T.S.; de Souza-Motta, C.M.; Porto, A.L.F. Potential application of waste from castor bean (Ricinus communis L.) for production for xylanase of interest in the industry. 3 Biotech 2016, 6, 144-154.

123. Pandya, J.J.; Gupte, A. Production of xylanase under solid-state fermentation by Aspergillus tubingensis JP-1 and its application. Bioprocess Biosyst. Eng. 2012, 35, 769-779. [CrossRef] [PubMed]

124. Asha Poorna, C.; Prema, P. Production of cellulase-free endoxylanase from novel alkalophilic thermotolerent Bacillus pumilus by solid-state fermentation and its application in wastepaper recycling. Bioresour. Technol. 2007, 98, 485-490. [CrossRef] [PubMed]

125. Zimbardi, A.L.R.L.; Sehn, C.; Meleiro, L.P.; Souza, F.H.M.; Masui, D.C.; Nozawa, M.S.F.; Guimarães, L.H.S.; Jorge, J.A.; Furriel, R.P.M. Optimization of $\beta$-Glucosidase, $\beta$-Xylosidase and Xylanase Production by Colletotrichum graminicola under Solid-State Fermentation and Application in Raw Sugarcane Trash Saccharification. Int. J. Mol. Sci. 2013, 14, 2875-2902. [CrossRef] [PubMed]

126. Chen, H.Q.; Chen, X.M.; Chen, T.X.; Xu, X.M.; Jin, Z.Y. Extraction optimization of inulinase obtained by solid state fermentation of Aspergillus ficuum JNSP5-06. Carbohydr. Polym. 2011, 85, 446-451. [CrossRef]

127. Mazutti, M.; Bender, J.P.; Treichel, H.; Luccio, M. Di Optimization of inulinase production by solid-state fermentation using sugarcane bagasse as substrate. Enzyme Microb. Technol. 2006, 39, 56-59. [CrossRef]

128. Martínez-Morales, F.; Bertrand, B.; Pasión Nava, A.A.; Tinoco, R.; Acosta-Urdapilleta, L.; Trejo-Hernández, M.R. Production, purification and biochemical characterization of two laccase isoforms produced by Trametes versicolor grown on oak sawdust. Biotechnol. Lett. 2015, 37, 391-396. [CrossRef] [PubMed]

129. El-Gindy, A.A.; Saad, R.R.; Fawzi, E.M. Purification of $\beta$-xylosidase from Aspergillus tamarii using ground oats and a possible application on the fermented hydrolysate by Pichia stipitis. Ann. Microbiol. 2015, 65, 965-974. [CrossRef]

130. López, J.A.; Lázaro, C.D.C.; Castilho, L.D.R.; Freire, D.M.G.; Castro, A.M.H. De Characterization of multienzyme solutions produced by solid-state fermentation of babassu cake, for use in cold hydrolysis of raw biomass. Biochem. Eng. J. 2013, 77, 231-239. [CrossRef] 
131. Kriaa, M.; Kammoun, R. Producing Aspergillus tubingensis CTM507 Glucose oxidase by Solid state fermentation versus submerged fermentation: Process optimization and enzyme stability by an intermediary metabolite in relation with diauxic growth. J. Chem. Technol. Biotechnol. 2016, 91, 1540-1550. [CrossRef]

132. Ali, H.K.Q.; Zulkali, M.M.D. Utilization of Agro-Residual Ligno-Cellulosic Substances by Using Solid State Fermentation: A Review. Croat. J. Food Technol. Biotechnol. Nutr. 2011, 6, 5-12.

133. Bezalwar, P.; Gomashe, A.V.; Sanap, H.M.; Gulhane, P.A. Original Research Article Production and Optimization of Citric Acid by Aspergillus niger using Fruit Pulp Waste Aspergillus niger culture maintenance. Int. J. Curr. Microbiol. Appl. Sci. 2013, 2, 347-352.

134. Goud, K.H.; Srilakshmi, A.; Kumar, P.A.; Narasimha, G. Citric acid production by aspergillus niger through solid state fermentation using fruit wastes. Biotechnol. Indian J. 2012, 6, 93-96.

135. Kumar, D.; Jain, V.K.; Shanker, G.; Srivastava, A. Utilization of fruits waste for citric acid production by solid state fermentation. Process Biochem. 2003, 38, 1725-1729. [CrossRef]

136. Dhillon, G.S.; Brar, S.K.; Verma, M.; Tyagi, R.D. Utilization of different agro-industrial wastes for sustainable bioproduction of citric acid by Aspergillus niger. Biochem. Eng. J. 2011, 54, 83-92. [CrossRef]

137. Hamdy, H.S. Citric acid production by Aspergillus niger grown on orange peel medium fortified with cane molasses. Ann. Microbiol. 2013, 63, 267-278. [CrossRef]

138. Karthikeyan, A.; Sivakumar, N. Citric acid production by Koji fermentation using banana peel as a novel substrate. Bioresour. Technol. 2010, 101, 5552-5556. [CrossRef] [PubMed]

139. Kareem, S.O.; Rahman, R.A. Utilization of banana peels for citric acid production by Aspergillus niger. Agric. Biol. J. N. Am. 2011, 4, 384-387. [CrossRef]

140. Torrado, A.M.; Cortes, S.; Salgado, J.M.; Max, B.; Rodriguez, N.; Bibbins, B.P.; Converti, A.; Dominguez, J.M. Citric acid production from orange peel wastes by solid-state fermentation. Braz. J. Microbiol. 2011, 42, 394-409. [CrossRef] [PubMed]

141. Krishna, C. Solid-State Fermentation Systems-An Overview. Crit. Rev. Biotechnol. 2005, 25, 1-30. [CrossRef] [PubMed]

142. Alam, M.Z.; Bari, M.N.; Muyibi, S.A.; Jamal, P.; Al-Mamun, A. Development of culture inoculum for scale-up production of citric acid from oil palm empty fruit bunches by Aspergillus niger. Procedia Environ. Sci. 2011, 8, 396-402. [CrossRef]

143. Yadegary, M.; Hamidi, A.; Alavi, S.A.; Khodaverdi, E.; Sattari, S.; Bagherpour, G.; Yahaghi, E. Citric acid production from sugarcane bagasse through solid state fermentation method using Aspergillus niger mold and optimization of citric acid production by taguchi method. Jundishapur J. Microbiol. 2013, 6, 1-6. [CrossRef]

144. Prado, F.C.; Vandenberghe, L.P.S.; Woiciechowski, A.L.; Rodrígues-Léon, J.A.; Soccol, C.R. Citric acid production by solid-state fermentation on a semi-pilot scale using different percentages of treated cassava bagasse. Braz. J. Chem. Eng. 2005, 22, 547-555. [CrossRef]

145. Schneider, M.; Zimmer, G.F.; Cremonese, E.B.; De, C.D.S.S.R.; Corbellini, V.A. By-products from the biodiesel chain as a substrate to citric acid production by solid-state fermentation. Waste Manag. Res. 2014, 32, 653-660. [CrossRef] [PubMed]

146. Hayihama, S.; Suwazono, W. The Use of Rhizopus sp. mutant for Lactic Acid Production by Solid State Fermentation. KKU Res. J. 2016, 22, 52-58.

147. John, R.P.; Nampoothiri, K.M.; Pandey, A. Solid-state fermentation for L-lactic acid production from agro wastes using Lactobacillus delbrueckii. Process Biochem. 2006, 41, 759-763. [CrossRef]

148. Rojan, P.J.; Nampoothiri, K.M.; Nair, A.S.; Pandey, A. L(+)-lactic acid production using Lactobacillus casei in solid-state fermentation. Biotechnol. Lett. 2005, 27, 1685-1688. [CrossRef] [PubMed]

149. Qi, B.; Yao, R. L-Lactic acid production from Lactobacillus casei by solid state fermentation using rice straw. BioResources 2007, 2, 419-429.

150. Altaf, M.; Naveena, B.J.; Venkateshwar, M.; Kumar, E.V.; Reddy, G. Single step fermentation of starch to L(+) lactic acid by Lactobacillus amylophilus GV6 in SSF using inexpensive nitrogen sources to replace peptone and yeast extract-Optimization by RSM. Process Biochem. 2006, 41, 465-472. [CrossRef]

151. Gowdhaman, D.; Sugumaran, K.R.; Ponnusami, V. Optimization of lactic acid production from tea waste by lactobacillus plantarum MTCC 6161 in solid state fermentation by central composite design. Int. J. ChemTech Res. 2012, 4, 143-148.

152. Ghosh, M.K.; Ghosh, U.K. Utilization of Pine needles as bed material in solid state fermentation for production of Lactic acid by Lactobacillus strains. BioResources 2011, 6, 1556-1575. 
153. Ghosh, U.K.; Ghosh, M.K. Utilization of Wheat Bran as Bed Material in Solid State Bacterial Production of Lactic Acid with Various Nitrogen Sources. Int. J. Biol. Biomol. Agric. Food Biotechnol. Eng. 2012, 6, 90-93.

154. El-Naggar, N.E.A.; El-Hersh, M.S. Organic acids associated with saccharification of cellulosic wastes during solid-state fermentation. J. Microbiol. 2011, 49, 58-65. [CrossRef] [PubMed]

155. Mai, H.T.N.; Lee, K.M.; Choi, S.S. Enhanced oxalic acid production from corncob by a methanol-resistant strain of Aspergillus niger using semi solid-sate fermentation. Process Biochem. 2016, 51, 9-15. [CrossRef]

156. De Vrije, T.; Antoine, N.; Buitelaar, R.M.; Bruckner, S.; Dissevelt, M.; Durand, A.; Gerlagh, M.; Jones, E.E.; Lüth, P.; Oostra, J.; et al. The fungal biocontrol agent Coniothyrium minitans: Production by solid-state fermentation, application and marketing. Appl. Microbiol. Biotechnol. 2001, 56, 58-68. [CrossRef] [PubMed]

157. Oostra, J.; Tramper, J.; Rinzema, A. Model-based bioreactor selection for large-scale solid-state cultivation of Coniothyrium minitans spores on oats. Enzyme Microb. Technol. 2000, 27, 652-663. [CrossRef]

158. Viccini, G.; Mannich, M.; Capalbo, D.M.F.; Valdebenito-Sanhueza, R.; Mitchell, D.A. Spore production in solid-state fermentation of rice by Clonostachys rosea, a biopesticide for gray mold of strawberries. Process Biochem. 2007, 42, 275-278. [CrossRef]

159. Zhang, Y.; Liu, J.; Zhou, Y.; Ge, Y. Spore Production of Clonostachys rosea in a New Solid-state Fermentation Reactor. Appl. Biochem. Biotechnol. 2014, 174, 2951-2959. [CrossRef] [PubMed]

160. Mishra, S.; Kumar, P.; Malik, A. Suitability of agricultural by-products as production medium for spore production by Beauveria bassiana HQ917687. Int. J. Recycl. Org. Waste Agric. 2016, 5, 179-184. [CrossRef]

161. Vijith, C.C.; Thota, S.G.; Vivek, A.T.; Gopinathan, C. Improved Bacillus thuringiensisbased biopesticide production using cheap carbon and nitrogen sources by solid state fermentation technique. IOSR J. Environ. Sci. Food Technol. 2016, 10, 49-53.

162. Jisha, V.N.; Benjamin, S. Solid-State Fermentation for the Concomitant Production of $\delta$-Endotoxin and Endospore from Bacillus thuringiensis subsp. kurstaki. Adv. Biosci. Biotechnol. 2014, 5, 797-804. [CrossRef]

163. Smitha, R.B.; Jisha, V.N.; Pradeep, S.; Josh, M.S.; Benjamin, S. Potato flour mediated solid-state fermentation for the enhanced production of Bacillus thuringiensis-toxin. J. Biosci. Bioeng. 2013, 116, 595-601. [CrossRef] [PubMed]

164. Zhuang, L.; Zhou, S.; Wang, Y.; Liu, Z.; Xu, R. Cost-effective production of Bacillus thuringiensis biopesticides by solid-state fermentation using wastewater sludge: Effects of heavy metals. Bioresour. Technol. 2011, 102, 4820-4826. [CrossRef] [PubMed]

165. Zhang, W.; Qiu, L.; Gong, A.; Cao, Y.; Wang, B. Solid-state Fermentation of Kitchen Waste for Production of Bacillus thuringiensis-based Bio-pesticide. BioResources 2013, 8, 1124-1135. [CrossRef]

166. Ballardo, C.; Abraham, J.; Barrena, R.; Artola, A.; Gea, T.; Sánchez, A. Valorization of soy waste through SSF for the production of compost enriched with Bacillus thuringiensis with biopesticide properties. J. Environ. Manag. 2016, 169, 126-131. [CrossRef] [PubMed]

167. De, S.; Malik, S.; Ghosh, A.; Saha, R.; Saha, B. A Review on Natural Surfactants. RSC Adv. 2015, 5, 65757-65767. [CrossRef]

168. Winterburn, J.B.; Martin, P.J. Foam mitigation and exploitation in biosurfactant production. Biotechnol. Lett. 2012, 34, 187-195. [CrossRef] [PubMed]

169. Velioglu, Z.; Urek, R.O. Physicochemical and structural characterization of biosurfactant produced by Pleurotus djamor in solid-state fermentation. Biotechnol. Bioprocess Eng. 2016, 21, 430-438. [CrossRef]

170. Zouari, R.; Ellouze-Chaabouni, S.; Ghribi-Aydi, D. Optimization of Bacillus subtilis SPB1 Biosurfactant Production Under Solid-state Fermentation Using By-products of a Traditional Olive Mill Factory. Achieve Life Sci. 2014, 8, 162-169. [CrossRef]

171. Zhu, Z.; Zhang, G.; Luo, Y.; Ran, W.; Shen, Q. Production of lipopeptides by Bacillus amyloliquefaciens XZ-173 in solid state fermentation using soybean flour and rice straw as the substrate. Bioresour. Technol. 2012, 112, 254-260. [CrossRef] [PubMed]

172. Zhu, Z.; Zhang, F.; Wei, Z.; Ran, W.; Shen, Q. The usage of rice straw as a major substrate for the production of surfactin by Bacillus amyloliquefaciens XZ-173 in solid-state fermentation. J. Environ. Manag. 2013, 127, 96-102. [CrossRef] [PubMed]

173. Slivinski, C.T.; Mallmann, E.; De Araújo, J.M.; Mitchell, D.A.; Krieger, N. Production of surfactin by Bacillus pumilus UFPEDA 448 in solid-state fermentation using a medium based on okara with sugarcane bagasse as a bulking agent. Process Biochem. 2012, 47, 1848-1855. [CrossRef] 
174. Sitohy, M.Z.; Rashad, M.M.; Sharobeem, S.F.; Mahmoud, A.E.; Nooman, M.U.; Kashef, A.S. Al Bioconversion of soy processing waste for production of surfactants. J. Microbiol. 2010, 4, 2811-2821.

175. Das, K.; Mukherjee, A.K. Comparison of lipopeptide biosurfactants production by Bacillus subtilis strains in submerged and solid state fermentation systems using a cheap carbon source: Some industrial applications of biosurfactants. Process Biochem. 2007, 42, 1191-1199. [CrossRef]

176. Parekh, V.J.; Pandit, A.B. Solid state fermentation (SSF) for the production of sophorolipids from Starmerella bombicola NRRL Y-17069 using glucose, wheat bran and oleic acid. Curr. Trends Biotechnol. Pharm. 2012, 6, 418-424.

177. Jimémenz-Peñalver, P.; Gea, T.; Sánchez, A.; Font, X. Production of sophorolipids from winterization oil cake by Solid-state fermentation: Optimization, monitoring and effect of mixing. Biochem. Eng. J. 2016, 115, 93-100. [CrossRef]

178. Camilios-Neto, D.; Bugay, C.; De Santana-Filho, A.P.; Joslin, T.; De Souza, L.M.; Sassaki, G.L.; Mitchell, D.A.; Krieger, N. Production of rhamnolipids in solid-state cultivation using a mixture of sugarcane bagasse and corn bran supplemented with glycerol and soybean oil. Appl. Microbiol. Biotechnol. 2011, 89, 1395-1403. [CrossRef] [PubMed]

179. Rodríguez, L.A.; Toro, M.E.; Vazquez, F.; Correa-Daneri, M.L.; Gouiric, S.C.; Vallejo, M.D. Bioethanol production from grape and sugar beet pomaces by solid-state fermentation. Int. J. Hydrogen Energy 2010, 35, 5914-5917. [CrossRef]

180. Chintagunta, A.D.; Jacob, S.; Banerjee, R. Integrated bioethanol and biomanure production from potato waste. Waste Manag. 2016, 49, 320-325. [CrossRef] [PubMed]

181. Du, R.; Yan, J.; Feng, Q.; Li, P.; Zhang, L.; Chang, S.; Li, S. A novel wild-type saccharomyces cerevisiaestrain TSH1 in scaling-up of solid-state fermentation of ethanol from sweet sorghum stalks. PLoS ONE 2014, 9, 94480-94490. [CrossRef] [PubMed]

182. Uçkun Kiran, E.; Liu, Y. Bioethanol production from mixed food waste by an effective enzymatic pretreatment. Fuel 2015, 159, 463-469. [CrossRef]

183. Liu, Y.; Zhang, Y.; Xu, J.; Sun, Y.; Yuan, Z.; Xie, J. Consolidated bioprocess for bioethanol production with alkali-pretreated sugarcane bagasse. Appl. Energy 2015, 157, 517-522. [CrossRef]

184. Ang, S.K.; Adibah, Y.; Abd-Aziz, S.; Madihah, M.S. Potential Uses of Xylanase-Rich Lignocellulolytic Enzymes Cocktail for Oil Palm Trunk (OPT) Degradation and Lignocellulosic Ethanol Production. Energy Fuels 2015, 29, 5103-5116. [CrossRef]

185. Thomas, L.; Parameswaran, B.; Pandey, A. Hydrolysis of pretreated rice straw by an enzyme cocktail comprising acidic xylanase from Aspergillus sp. for bioethanol production. Renew. Energy 2016, 98, 9-15. [CrossRef]

186. Suresh, S.V.; Srujana, S.; Muralidharan, A. Production of bioethanol by Solid State Fermentation using paddy straw as a substrate. Int. J. Adv. Res. 2015, 3, 212-215.

187. Ingale, S.; Joshi, S.J.; Gupte, A. Production of bioethanol using agricultural waste: Banana pseudo stem. Braz. J. Microbiol. 2014, 45, 885-892. [CrossRef] [PubMed]

188. Pirota, R.D.P.B.; Delabona, P.S.; Farinas, C.S. Simplification of the Biomass to Ethanol Conversion Process by Using the Whole Medium of Filamentous Fungi Cultivated Under Solid-State Fermentation. Bioenergy Res. 2014, 7, 744-752. [CrossRef]

189. Singhania, R.R.; Saini, R.; Adsul, M.; Saini, J.K.; Mathur, A.; Tuli, D. An integrative process for bio-ethanol production employing SSF produced cellulase without extraction. Biochem. Eng. J. 2015, 102, 45-48. [CrossRef]

190. Jain, A.; Morlok, C.K.; Henson, J.M. Comparison of solid-state and submerged-state fermentation for the bioprocessing of switchgrass to ethanol and acetate by Clostridium phytofermentans. Appl. Microbiol. Biotechnol. 2013, 97, 905-917. [CrossRef] [PubMed]

191. Yu, M.; Li, J.; Li, S.; Du, R.; Jiang, Y.; Fan, G.; Zhao, G.; Chang, S. A cost-effective integrated process to convert solid-state fermented sweet sorghum bagasse into cellulosic ethanol. Appl. Energy 2014, 115, 331-336. [CrossRef]

192. Yu, M.; Li, J.; Chang, S.; Zhang, L.; Mao, Y.; Cui, T.; Yan, Z.; Luo, C.; Li, S. Bioethanol production using the sodium hydroxide pretreated sweet sorghum bagasse without washing. Fuel 2016, 175, 20-25. [CrossRef]

193. Izawa, N.; Kudo, M.; Nakamura, Y.; Mizukoshi, H.; Kitada, T.; Sone, T. Production of aroma compounds from whey using Wickerhamomyces pijperi. AMB Express 2015, 5, 23. [CrossRef] [PubMed] 
194. Ben Akacha, N.; Gargouri, M. Microbial and enzymatic technologies used for the production of natural aroma compounds: Synthesis, recovery modeling, and bioprocesses. Food Bioprod. Process. 2015, 94, 675-706. [CrossRef]

195. Madrera, R.R.; Bedriñana, R.P.; Valles, B.S. Production and characterization of aroma compounds from apple pomace by solid-state fermentation with selected yeasts. LWT Food Sci. Technol. 2015, 64, 1342-1353. [CrossRef]

196. Aggelopoulos, T.; Katsieris, K.; Bekatorou, A.; Pandey, A.; Banat, I.M.; Koutinas, A.A. Solid state fermentation of food waste mixtures for single cell protein, aroma volatiles and fat production. Food Chem. 2014, 145, 710-716. [CrossRef] [PubMed]

197. Pedroni Medeiros, A.B.; Christen, P.; Roussos, S.; Gern, J.C.; Soccol, C.R. Coffee residues as substrates for aroma production by Ceratocystis fimbriata in solid state fermentation. Braz. J. Microbiol. 2003, 34, 245-248. [CrossRef]

198. Medeiros, A.B.P.; Pandey, A.; Vandenberghe, L.P.S.; Pastorel, G.M.; Soccol, C.R. Production and recovery of aroma compounds produced by solid-state fermentation using different adsorbents. Food Technol. Biotechnol. 2006, 44, 47-52.

199. Soares, M.; Christen, P.; Pandey, A. Fruity flavor production by Ceratocystis fimbriata grown on coffe husk in solid-state fermentation. Process Biochem. 2000, 35, 857-861. [CrossRef]

200. Rossi, S.C.; Vandenberghe, L.P.S.; Pereira, B.M.P.; Gago, F.D.; Rizzolo, J.A.; Pandey, A.; Soccol, C.R.; Medeiros, A.B.P. Improving fruity aroma production by fungi in SSF using citric pulp. Food Res. Int. 2009, 42, 484-486. [CrossRef]

201. Medeiros, A.B.P.; Pandey, A.; Christen, P.; Fontoura, P.S.G.; de Freitas, R.J.S.; Soccol, C.R. Aroma compounds produced by Kluyveromyces marxianus in solid state fermentation on a packed bed column bioreactor. World J. Microbiol. Biotechnol. 2001, 17, 767-771. [CrossRef]

202. De Aráujo, Á.; Pastore, G.M.; Berger, R.G. Production of coconut aroma by fungi cultivation in solid-state fermentation. Appl. Biochem. Biotechnol. 2002, 98-100, 747-751.

203. Fadel, H.H.M.; Mahmoud, M.G.; Asker, M.M.S.; Lotfy, S.N. Characterization and evaluation of coconut aroma produced by Trichoderma viride EMCC-107 in solid state fermentation on sugarcane bagasse. Electron. J. Biotechnol. 2015, 18, 5-9. [CrossRef]

204. Da Penha, M.P.; da Rocha Leão, M.H.M.; Leite, S.G.F. Sugarcane bagasse as support for the production of coconut aroma by solid state fermentation (SSF). BioResources 2012, 7, 2366-2375. [CrossRef]

205. Kabbaj, W.; Breheret, S.; Guimberteau, J.; Talou, T.; Olivier, J.-M.; Bensoussan, M.; Sobal, M.; Roussos, A.S. Comparison of Volatile Compound Production in Fruit Body and in Mycelium of Pleurotus ostreatus Identified by Submerged and Solid-State Cultures. Appl. Biochem. Biotechnol. 2002, 102-103, 463-469. [CrossRef]

206. Omarini, A.; Dambolena, J.S.; Lucini, E.; Jaramillo Mejía, S.; Albertó, E.; Zygadlo, J.A. Biotransformation of 1,8-cineole by solid-state fermentation of Eucalyptus waste from the essential oil industry using Pleurotus ostreatus and Favolus tenuiculus. Folia Microbiol. 2016, 61, 149-157. [CrossRef] [PubMed]

207. Zidehsaraei, A.Z.; Moshkelani, M.; Amiri, M.C. An innovative simultaneous glucoamylase extraction and recovery using colloidal gas aphrons. Sep. Purif. Technol. 2009, 67, 8-13. [CrossRef]

208. Dhillon, G.S.; Brar, S.K.; Kaur, S.; Verma, M. Bioproduction and extraction optimization of citric acid from Aspergillus niger by rotating drum type solid-state bioreactor. Ind. Crops Prod. 2013, 41, 78-84. [CrossRef]

209. Pirota, R.D.P.B.; Miotto, L.S.; Delabona, P.S.; Farinas, C.S. Improving the extraction conditions of endoglucanase produced by Aspergillus niger under solid-state fermentation. Braz. J. Chem. Eng. 2013, 30, 117-123. [CrossRef]

210. Arantes, V.; Silva, E.M.; Milagres, A.M.F. Optimal recovery process conditions for manganese-peroxidase obtained by solid-state fermentation of eucalyptus residue using Lentinula edodes. Biomass Bioenergy 2011, 35, 4040-4044. [CrossRef]

211. Chandra, M.S.; Viswanath, B.; Reddy, B.R. Optimization of extraction of beta-endoglucanase from the fermented bran of Aspergillus niger. Indian J. Microbiol. 2010, 50, S122-S126. [CrossRef] [PubMed]

212. Ahmed, S.A.; Mostafa, F.A. Utilization of orange bagasse and molokhia stalk for production of pectinase enzyme. Braz. J. Chem. Eng. 2013, 30, 449-456. [CrossRef] 
213. Rodríguez-Fernández, D.E.; Rodríguez-León, J.A.; de Carvalho, J.C.; Thomaz-Soccol, V.; Parada, J.L.; Soccol, C.R. Recovery of phytase produced by solid-state fermentation on citrus peel. Braz. Arch. Biol. Technol. 2010, 53, 1487-1496. [CrossRef]

214. Dey, T.B.; Kuhad, R.C. Enhanced production and extraction of phenolic compounds from wheat by solid-state fermentation with Rhizopus oryzae RCK2012. Biotechnol. Rep. 2014, 4, 120-127.

215. Salariato, D.; Diorio, L.A.; Mouso, N.; Forchiassin, F. Extraction and characterization of polygalacturonase of fomes sclerodermeus produced by solid-state fermentation. Rev. Argent. Microbiol. 2010, 42, 57-62. [PubMed]

216. Szabo, O.E.; Csiszar, E.; Koczka, B.; Kiss, K. Ultrasonically assisted single stage and multiple extraction of enzymes produced by Aspergillus oryzae on a lignocellulosic substrate with solid-state fermentation. Biomass Bioenergy 2015, 75, 161-169. [CrossRef]

217. Rezaei, F.; Joh, L.D.; Kashima, H.; Reddy, A.P.; Vandergheynst, J.S. Selection of conditions for cellulase and xylanase extraction from switchgrass colonized by acidothermus cellulolyticus. Appl. Biochem. Biotechnol. 2011, 164, 793-803. [CrossRef] [PubMed]

218. Poletto, P.; Borsói, C.; Zeni, M.; Moura, M. Downstream processing of pectinase produced by Aspergillus niger in solid state cultivation and its application to fruit juices clarification. Food Sci. Technol. 2015, 35, 391-397. [CrossRef]

219. Rashad, M.M.; Nooman, M.U.; Ali, M.M.; Mahmoud, A.E. Production, characterization and anticancer activity of Candida bombicola sophorolipids by means of solid state fermentation of sunflower oil cake and soybean oil. Grasas Aceites 2014, 65, 1-11. [CrossRef]

220. Hu, Y.; Ju, L.K. Purification of lactonic sophorolipids by crystallization. J. Biotechnol. 2001, 87, $263-272$. [CrossRef]

221. Bhavsar, K.; Ravi Kumar, V.; Khire, J.M. Downstream processing of extracellular phytase from Aspergillus niger: Chromatography process vs. aqueous two phase extraction for its simultaneous partitioning and purification. Process Biochem. 2012, 47, 1066-1072.

222. Kachrimanidou, V.; Kopsahelis, N.; Vlysidis, A.; Papanikolaou, S.; Kookos, I.K.; Monje Martinez, B.; Escrig Rondan, M.C.; Koutinas, A.A. Downstream separation of poly(hydroxyalkanoates) using crude enzyme consortia produced via solid state fermentation integrated in a biorefinery concept. Food Bioprod. Process. 2016, 100, 323-334. [CrossRef]

223. Narra, M.; Balasubramanian, V. Utilization of solid and liquid waste generated during ethanol fermentation process for production of gaseous fuel through anaerobic digestion-A zero waste approach. Bioresour. Technol. 2015, 180, 376-380. [CrossRef] [PubMed]

224. Dhillon, G.S.; Kaur, S.; Sarma, S.J.; Brar, S.K. Integrated process for fungal citric acid fermentation using apple processing wastes and sequential extraction of chitosan from waste stream. Ind. Crops Prod. 2013, 50, 346-351. [CrossRef]

225. Zhang, Z.Y.; Jin, B.; Kelly, J.M. Production of lactic acid from renewable materials by Rhizopus fungi. Biochem. Eng. J. 2007, 35, 251-263. [CrossRef]

226. Zhuang, J.; Marchant, M.A.; Nokes, S.E.; Strobel, H.J. Economic analysis of cellulase production methods for bio-ethanol. Appl. Eng. Agric. 2007, 23, 679-687. [CrossRef]

227. De Castro, A.M.; Carvalho, D.F.; Freire, D.M.G.; Castilho, L.D.R. Economic analysis of the production of amylases and other hydrolases by Aspergillus awamori in solid-state fermentation of Babassu Cake. Enzyme Res. 2010, 2010, 1-9.

(C) 2017 by the authors; licensee MDPI, Basel, Switzerland. This article is an open access article distributed under the terms and conditions of the Creative Commons Attribution (CC BY) license (http:/ / creativecommons.org/licenses/by/4.0/). 